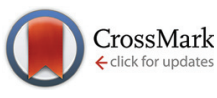

Cite this: Org. Biomol. Chem., 2015, 13,5147

Received 10th March 2015

Accepted 27th March 2015

DOI: $10.1039 / \mathrm{c} 50 \mathrm{~b} 00474 \mathrm{~h}$

www.rsc.org/obc

\section{Direct and two-step bioorthogonal probes for Bruton's tyrosine kinase based on ibrutinib: a comparative study $\dagger$}

\author{
Nora Liu, ${ }^{a}$ Sascha Hoogendoorn, ${ }^{a}$ Bas van de Kar, ${ }^{\text {b }}$ Allard Kaptein, ${ }^{\text {b }}$ Tjeerd Barf, ${ }^{\text {b }}$ \\ Christoph Driessen, ${ }^{C}$ Dmitri V. Filippov, ${ }^{a}$ Gijsbert A. van der Marel, ${ }^{a}$ \\ Mario van der Stelt*a and Herman S. Overkleeft*a
}

\begin{abstract}
Ibrutinib is a covalent and irreversible inhibitor of Bruton's tyrosine kinase (BTK) and has been approved for the treatment of haematological malignancies, such as chronic lymphocytic leukaemia, mantle cell lymphoma and Waldenström's macroglobulinemia. The covalent and irreversible nature of its molecular mode of action allows identification and monitoring of its target in an activity-based protein profiling (ABPP) setting. Fluorescent and biotinylated ibrutinib derivatives have appeared in the literature in recent years to monitor BTK in vitro and in situ. The work described here complements this existing methodology and pertains a comparative study on the efficacy of direct and two-step bioorthogonal ABPP of BTK.
\end{abstract}

\section{Introduction}

Bruton's tyrosine kinase (BTK), a nonreceptor tyrosine kinase member of the Tec kinase family, is involved in B cell receptor (BCR) signalling and governs B-lymphocyte development, differentiation, signalling and survival. ${ }^{1}$ Aberrant BTK activity is a fundamental feature of the human B-cell malignancies; chronic lymphocytic leukaemia (CLL), mantle cell lymphoma (MCL), follicular lymphoma (FL), diffuse large B-cell lymphoma (DLBCL), and Waldenström's macroglobulinemia (WM). ${ }^{2}$

The first-in-class BTK-inhibitor ibrutinib (Imbruvica ${ }^{\circledR}$, PCI-32765, 1, Fig. 1) has recently been approved for the treatment of WM, MCL and CLL by the FDA. ${ }^{3}$ Apart from its clinical efficacy, ibrutinib is of interest because of its mechanism of action. Ibrutinib irreversibly blocks BTK activity through covalent modification of Cys481 within the enzyme ATPbinding pocket following conjugate addition of the cysteine thiol to the acrylamide moiety in $\mathbf{1}$ (Fig. 1), an event that prevents phosphorylation of Tyr223, an essential step for BTK activation. At present, numerous covalent kinase inactivators are pursued for a range of human malignancies. ${ }^{4}$ Besides the clinical relevance of mechanism-based inhibitors (long resi-

${ }^{a}$ Leiden Institute of Chemistry, Leiden University, Einsteinweg 55, 2300 RA Leiden, The Netherlands. E-mail: h.s.overkleeft@chem.leidenuniv.nl, m.van.der.stelt@chem.leidenuniv.nl

${ }^{b}$ AcertaPharma, Molenweg 795349 AC, Oss, The Netherlands

${ }^{c}$ Kantonspital St. Gallen, Rorschacher Strasse 95, St. Gallen, Switserland

$\dagger$ Electronic supplementary information (ESI) available. See DOI: 10.1039/ c5ob00474h

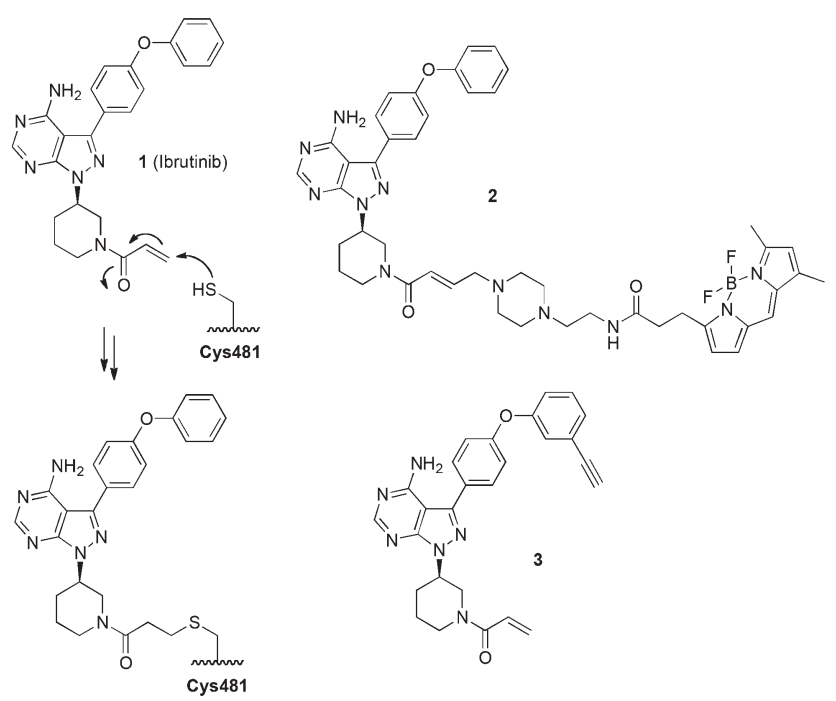

Fig. 1 Mechanism-based inactivation of Bruton's tyrosine kinase (BTK) by ibrutinib (1) (left) and the direct (2) and two-step (3) BTK activitybased probes reported to date (right).

dence time, lasting inhibitory effect which is only dependent on de novo synthesis of the protein target), covalent and irreversible enzyme inhibitors are highly useful starting points for the development of activity-based protein profiling (ABPP) probes. ${ }^{5}$ Such probes, also termed activity-based probes (ABPs), are composed of a mechanism-based enzyme inhibitor modified to contain an identification tag, which can be a biotin (for visualisation and/or enrichment), a fluorophore (for 

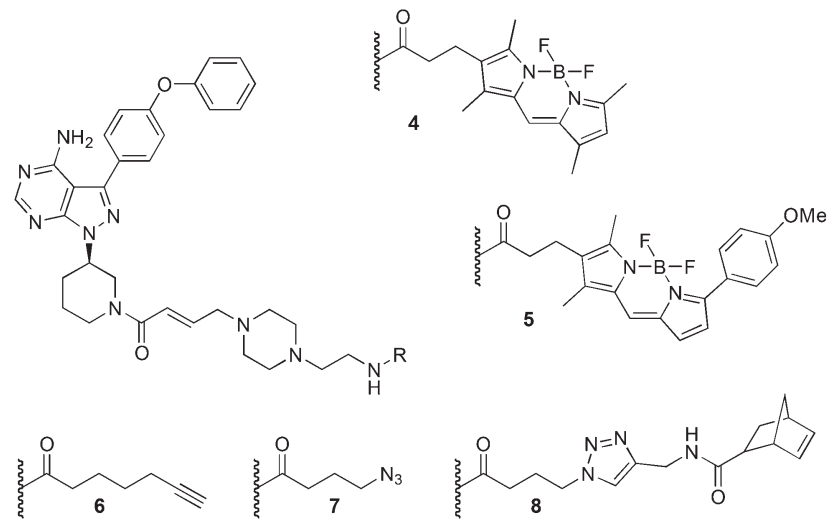

Fig. 2 Direct (4 and 5) and two-step bioorthogonal (6-8) BTK activitybased probes that are subject of the here presented study.

visualisation), or a bioorthogonal tag (to install a fluorophore or affinity tag following enzyme labelling).

In the recent literature both direct and two-step bioorthogonal ibrutinib-based ABPs have been described. Honigberg and co-workers reported on the development of BODIPY-FL-ibrutinib 2 and its application in detection of BTK in BTK-positive tumour cells and mouse models of autoimmune disease. ${ }^{3 c}$ Cravatt and co-workers in turn described ibrutinib-alkyne 3 as part of a series of alkyne-modified covalent kinase inhibitors in a broad-spectrum Huisgen [2 + 3]-cycloaddition 'click'based two-step ABPP study on kinase activities in a variety of tumour tissues. ${ }^{6}$

Our ABPP research focuses amongst others on the head-tohead comparison of direct and two-step bioorthogonal ABPP methodologies. ${ }^{7}$ In these studies we include assessment of the relative efficiency of established bioorthogonal chemistries including $\mathrm{Cu}(\mathrm{I})$-catalysed and strain-promoted azide-alkyne $[2+3]$ cycloaddition, Staudinger-Bertozzi ligation and inverseelectron demand Diels-Alder ligation. We have previously shown that with the exception of strain-promoted alkyne-azide cycloadditions all of the above are effective bioorthogonal chemistries in the two-step ABPP modification of the catalytic activities of mammalian proteasomes and moreover that these reactions can be executed consecutively in a multiplexing fashion in a single biological sample. ${ }^{8}$ We here report on a comparative study in which we probed for catalytically active BTK levels in BTK-positive Ramos cells with direct ABPs 4 and 5 (Fig. 2) as well as two-step ABPs 6 and $7(\mathrm{Cu}(\mathrm{I})$-catalysed azide-alkyne $[2+3]$ cycloaddition) and 8 (inverse-electron demand Diels-Alder).

\section{Results and discussion}

\section{Synthesis of ibrutinib and ibrutinib-based ABPs}

Perusal of the literature on structure-activity relationship studies on ibrutinib revealed that analogues featuring a piperazinyl extension at the acrylamide side of the parent compound are well tolerated by the target enzyme, BTK. Weissleder and

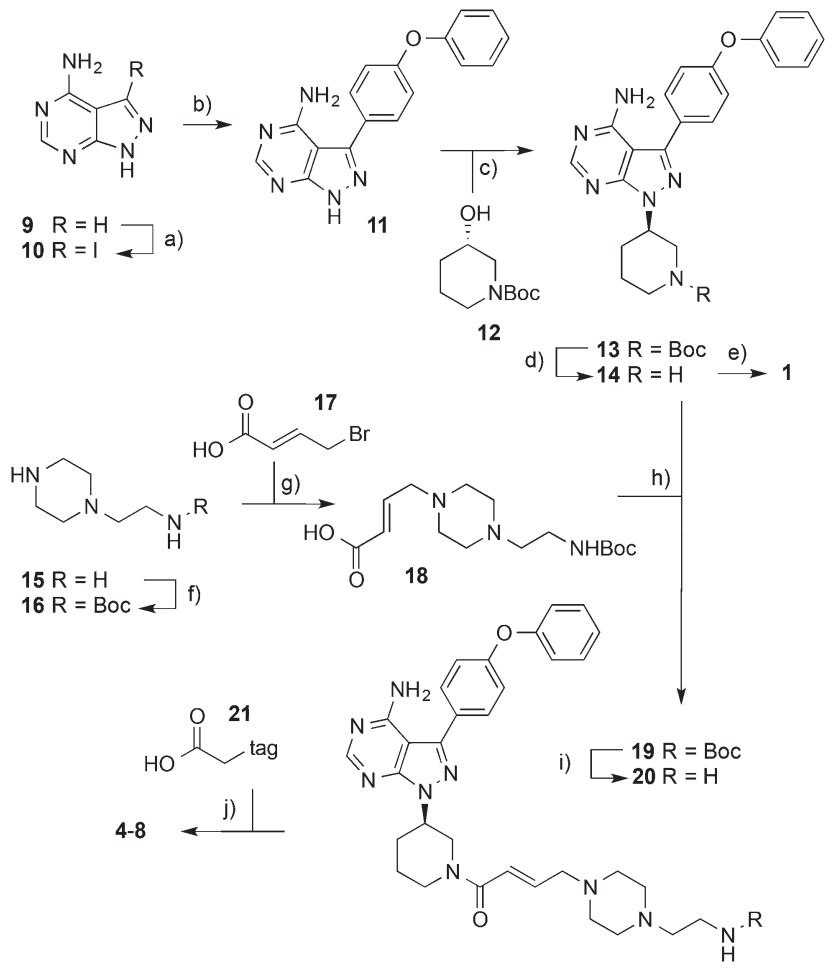

Scheme 1 Reagents and conditions: (a) $\mathrm{N}$-iodosuccinimide, $80{ }^{\circ} \mathrm{C}$, DMF, 87\%; (b) $\mathrm{K}_{3} \mathrm{PO}_{4}$, 4-phenoxybenzene boronic acid, $\mathrm{Pd}\left(\mathrm{PPh}_{3}\right)_{4}$, dioxane, $180{ }^{\circ} \mathrm{C}, 79 \%$; (c) $12, \mathrm{PPh}_{3}$ polymer-bound, DIAD, THF, 56\%; (d) 4.0 M HCl in dioxane, 100\%; (e) acryloyl chloride, TEA, DCM, 46\%; (f) (i) benzaldehyde, $\mathrm{Cbz}-\mathrm{Cl}$, toluene, 38\%; (ii) $\mathrm{Boc}_{2} \mathrm{O}, \mathrm{THF}, 79 \%$; (iii) $\mathrm{Pd} / \mathrm{C}, \mathrm{H}_{2}$, $\mathrm{MeOH}, 94 \%$; (g) 17, TEA, THF; (h) 14, HATU, TEA, DMF, $87 \%$; (i) $4.0 \mathrm{M} \mathrm{HCl}$ in dioxane, 100\%; (j) HATU, DiPEA, DMF, 21, 4: 17\%, 5: 10\%, 6: 36\%, 7: $22 \%, 8: 10 \%$.

co-workers used this finding in their design of direct BTK ABP 2 (Fig. 1). ${ }^{9}$ Based on these literature findings we decided to use ibrutinib derivative $\mathbf{2 0}$ (Scheme 1) as common core onto which the BODIPY fluorophores and two-step bioorthogonal ligation handles as depicted in Fig. 2 are grafted. Thus as the first research objective we set out to synthesise amine 20 (Scheme 1). Iodide $\mathbf{1 0}$ was prepared from commercially available aminopyrazolopyrimidine $\mathbf{9}$ in an electrophilic aromatic substitution using $N$-iodosuccinimide as the iodinating agent. Ensuing Suzuki coupling with 4-phenoxybenzene boronic acid according to the literature procedure provided diphenyl ether 11, which was reacted with enantiopure $(S)$ - $N$-Boc-3-hydroxypiperidine 12 under Mitsunobu conditions to give intermediate 13 with full inversion of stereochemistry. ${ }^{9,10}$ Acid mediated removal of the Boc protective group followed by condensation of the thus liberated secondary amine with acryloyl chloride gave ibrutinib 1, the analytical and spectral data of which were in full agreement with those reported in the literature. ${ }^{10,11}$

The synthesis of ABPs 4-8 requires access to piperazinefunctionalised acrylate 18, for which synthesis we adapted the patent literature. ${ }^{12}$ In the first instance, we attempted to prepare the precursor, single Boc-protected aminoethylpiperazine 16, as described by treatment of aminoethylpiperazine with di- 
tert-butyldicarbonate in the presence of benzyl aldehyde. However, this one-step procedure, not unexpectedly, ${ }^{13}$ failed. Therefore, we resorted to the following three-step procedure as depicted. ${ }^{14}$ Thus, in situ formation of the primary benzylimine and ensuing $\mathrm{Cbz}$ protection of the secondary amine and liberation of the primary amine yielded mono-Cbz-aminoethylpiperazine, with the secondary amine temporarily protected as the benzyloxycarbamate. Subsequent, introduction of the Boc protective group at this stage followed by hydrogenolysis of the Cbz group afforded compound 16, which was $N$-alkylated with $E$-bromobutenoic acid $17^{15}$ to yield compound 18. Condensation of 14 and 18 under the agency of HATU and triethylamine followed by acidic removal of the Boc group afforded ibrutinib derivative 20. Condensation (HATU, DiPEA) with the appropriately modified tags $\mathbf{2 1}$ (see for the used tags the Experimental section) afforded target direct ABPs $\mathbf{4}$ and $\mathbf{5}$ as well as the two-step bioorthogonal ABPs (6-8) in moderate yield but good purity after HPLC purification.

\section{Evaluation of the inhibitory potency and labelling efficiency}

We first established the potency of ABPs 4-8 as BTK inhibitors. Non-fluorescent derivatives 6-8 were measured in an immobilized metal ion affinity-based fluorescence polarization (IMAP) assay using recombinantly expressed human BTK with ibrutinib 1 included as benchmark. Fluorescent, direct ABPs 4 and 5 were added to Ramos cell extract, which contains endogenously expressed BTK, after which the protein content was denatured and resolved on SDS-PAGE.

As can be seen from Fig. 3A, ibrutinib analogues 6-8 inhibit recombinant, purified BTK with $\mathrm{IC}_{50}$ values in the same range as ibrutinib 1. The fluorescent analogues 4 and 5 are not compatible with the IMAP assay and thus we established whether these compounds would be able to detect ibrutinib in an activity-based protein profiling setting. As can be seen (Fig. 3B) both compounds label a single band with an apparent molecular weight corresponding to that of BTK. Of note, labelling of this protein could be prevented in a dosedependent manner by pre-incubation with ibrutinib (Fig. 3C).

We next set out to establish the ability of compounds 4-8 to target BTK in living cells. Fig. 4A shows that both green (4) and red (5) fluorescent probes readily and selectively modify BTK in a concentration-dependent manner and do so at concentrations as low as $100 \mathrm{nM}$ (for ABP 4). Thus both direct ABPs behave as expected, given the literature precedent. ${ }^{3 c}$ This makes the probes also useful for the assessment of the inhibitory potency and cell permeability of putative BTK inhibitors in a competitive ABPP setting.

To establish whether putative two-step ABPs 6-8 are able to reach and inhibit BTK in live cells, we treated living Ramos cells in culture with varying concentration of these compounds, prior to treatment with $\mathrm{ABP} \mathbf{4}$, cell lysis and SDS-PAGE. As is evident from Fig. 4B, the three compounds abolish labelling at the lowest concentration $(4 \mu \mathrm{M}$; approximately $10 \times \mathrm{IC}_{50}$ value for all compounds, see Fig. 3A) applied and we can thus conclude that all 5 compounds - direct and two-step ABPs - are able to modify BTK in live cells.
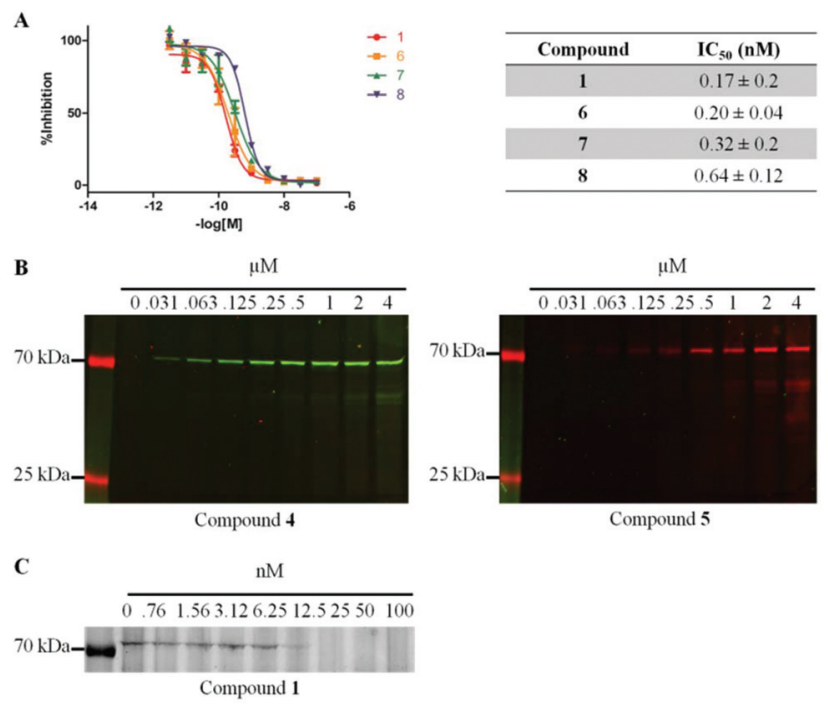

Fig. 3 (A) BTK inhibitory potency $\left(\mathrm{IC}_{50}\right)$ of ibrutinib 1 and two-step bioorthogonal ABPs $6-8$. The mean $I_{50}$ values are calculated from two independent experiments performed in duplicate. (B) BTK labelling efficiency of direct ABPs $\mathbf{4}$ and $\mathbf{5}$ in Ramos cell extract. Ramos cell extracts were exposed for $1 \mathrm{~h}$ at room temperature to the indicated concentrations of ABP 4 or $\mathbf{5}$. Three independent experiments were performed. (C) Competition experiments of ibrutinib 1 versus fluorescent ABP 4 in Ramos cell lysates. Three independent experiments were performed. Ramos cell extracts were exposed to the indicated concentrations of ibrutinib 1 for $1 \mathrm{~h}$ at room temperature and then incubated with ABP $4(1 \mu \mathrm{M})$ for $1 \mathrm{~h}$ at room temperature. Proteins were analysed by SDS-PAGE using detection by in-gel fluorescent readout. See for complete gels the ESI. $\dagger$ Lane 1: dual color protein standard.

Fig. 4C shows that BTK labelling with ABP 4 in live cells could be prevented in a dose-dependent manner by pre-incubation with ibrutinib, strongly suggesting BTK specificity of these probes in live cells.

The efficiency and selectivity of the two-step ABPs 6-8 to modify BTK in Ramos cell extracts was assessed next.

Fig. 5 depicts the complementary reagents used in these experiments, that is, BODIPY-FL-modified bioorthogonal reagent 22 (for copper(I)-catalysed alkyne-azide [2+3] cycloaddition (CuAAC) ligation to azide-modified ibrutinib 6), BODIPY-green-alkyne 23 (for copper(I)-catalysed click ligation to alkyne-modified ibrutinib 7) and BODIPY-FL-tetrazine 24 (for inverse-electron demand Diels-Alder ligation to norbornene-modified ibrutinib 8).

Ramos cell lysates were treated with ibrutinib-alkyne 6, ibrutinib-azide 7 or ibrutinib-norbonene 8 at $4 \mu \mathrm{M}$ final concentrations for one hour at room temperature. Next the samples were treated with the complementary bioorthogonal ligation handles 22-24 at various final concentrations for one hour. The proteins were resolved on SDS-PAGE and the wet gel slabs analysed by fluorescence read-out. As can be seen (Fig. 6A) both copper(I)-catalysed click reactions give BTK labelling in a concentration-dependent manner, as does the inverse-electron demand Diels-Alder (IEDDA) ligation. Though the two click ligation steps appear about equally effective in 
A
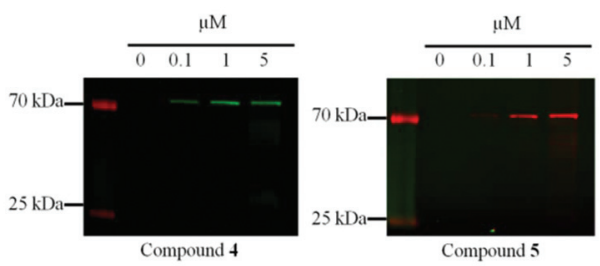

B

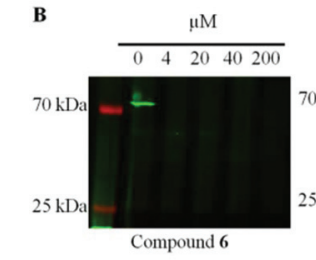

$\mu \mathrm{M}$
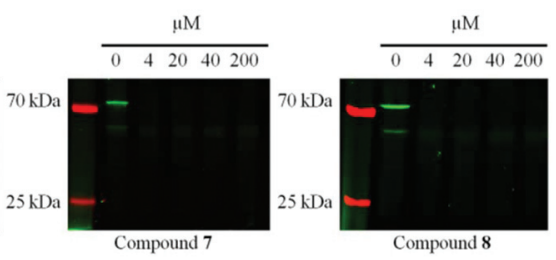

C

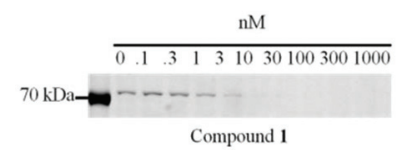

Fig. 4 (A) In situ labelling of BTK in Ramos cells by 4 and 5 . Ramos cells were exposed to the indicated concentrations of 4 or 5 for $4 \mathrm{~h}$ at $37^{\circ} \mathrm{C}$. Proteins were analysed by SDS-PAGE using detection by in-gel fluorescent readout. Three independent experiments were performed. (B) Competition experiments of BODIPY-FL-ibrutinib 4 versus compounds 6-8 in Ramos cells. Ramos cells were exposed to the indicated concentrations of 6,7 , or 8 for $3 \mathrm{~h}$ at $37^{\circ} \mathrm{C}$ and then lysed. The cell lysates were exposed to $1 \mu \mathrm{M}$ of ABP 4 for $1 \mathrm{~h}$ at room temperature. Two independent experiments were performed. (C) Competition experiments of ibrutinib 1 versus fluorescent ABP 4 in Ramos cells. Two independent experiments were performed. Ramos cells were exposed to the indicated concentrations of ibrutinib 1 for $3 \mathrm{~h}$ at $37^{\circ} \mathrm{C}$ and then lysed. The cell lysates were exposed to $1 \mu \mathrm{M}$ of ABP 4 for $1 \mathrm{~h}$ at room temperature. Proteins were analysed by SDS-PAGE using detection by in-gel fluorescent readout. See for complete gels the ESI. $\dagger$ Lane 1: dual colour protein standard.
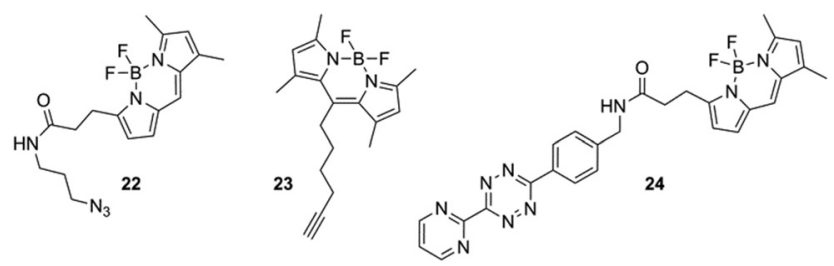

Fig. 5 Ligation reagents used in the here presented study.

terms of activity, differences are apparent when considering aspecific reaction of the (click/tetrazine) ligation handles, with alkyne-azide click ligation giving the optimal result. The IEDDA ligation appears to proceed equally selective though the labelling intensity appears somewhat lower.

As a final experiment we explored the ability of IEDDAbased ABP 8 to modify BTK in situ in living Ramos cells (Fig. 6D). For this purpose, we treated Ramos cells with $4 \mu \mathrm{M}$ 6-8 for 1 hour at $37^{\circ} \mathrm{C}$. For the purpose of the two CuAAC click ligations the cells were lysed, whereas IEDDA ligation (addition of norbornene 24) was performed in situ and in vitro. As can be seen (Fig. 6D) also these partial or complete in situ
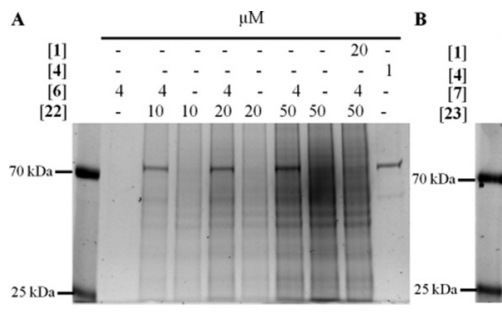

C

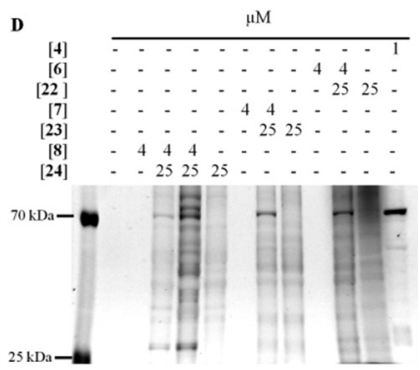

Fig. 6 (A-C) In vitro two-step bioorthogonal labelling of BTK in Ramos cell extract using reagent pairs (6/22), (7/23) and (8/24). Ramos cell lysates were exposed to ABP 6 or 7 for $1 \mathrm{~h}$ at room temperature and then reacted with the indicated concentrations of BODIPY-azide 22 or BODIPY-alkyne 23 for $1 \mathrm{~h}$ at room temperature. Copper-catalysed click reactions were performed in the presence of $\mathrm{CuSO}_{4}(6.5 \mathrm{mM})$, tris(3hydroxypropyltriazolylmethyl) amine THPTA $(6.5 \mathrm{mM})$ and sodium L-ascorbate $(6.5 \mathrm{mM})$. Alternatively, ABP $8(4 \mu \mathrm{M})$ was used for ligation with tetrazine 24. In control experiments different ligation strategies were performed in the absence of ABP 6-8 or after competition by an excess of ibrutinib 1 . As a positive control, extracts were labelled with fluorescent ABP $4(1 \mu M)$. Three independent experiments were performed. (D) Two-step bioorthogonal profiling of BTK activity by different ligation strategies. Ramos cells were exposed to ABP 6-8 $(4 \mu \mathrm{M})$ for $3 \mathrm{~h}$ at $37{ }^{\circ} \mathrm{C}$, washed, lysed, and then reacted with their corresponding ligation reagent 22-24 $(25 \mu \mathrm{M})$ for $1 \mathrm{~h}$ at room temperature. Alternatively, cells were consecutively exposed to ABP 8 and ligation reagent 24 in situ (lane 5). In control experiments different ligation strategies were performed in the absence of ABP 6-8 and/or ligation reagent. As a positive control, cells were labelled with fluorescent ABP $4(1 \mu \mathrm{M})$. Three independent experiments were performed. Proteins were analysed by SDS-PAGE using detection by in-gel fluorescent readout. Lane 1: dual color protein standard.

ligations proved successful. The two CuAAC ligations on $\mathbf{6}$ and 7 proved more selective compared to the IEDDA ligation, but with the caveat that the copper-catalysed click ligations need to be executed in cell extracts.

In conclusion, we have expanded the BTK activity-based probe set by the development of two direct ABPs $\mathbf{4}$ and $\mathbf{5}$ equipped with BODIPY fluorophores that emit at two distinct wavelengths, as well as three bioorthogonal two-step ABPs that can be addressed through either CuAAC or IEDDA bioorthogonal chemistry. As such our BTK imaging toolset adds to the existing BTK probes - both direct and two-step - for measuring catalytically active BTK in various settings. Though direct imaging with BODIPY-ibrutinib derivatives $\mathbf{4}$ and $\mathbf{5}$ appears most effective in live cells, the situation may differ in case live animals are to be subject of study and for this purpose the IEDDA bioorthogonal ABP pair 8/24 may be most effective even though labelling efficiency appears the lowest. In an alternative setting, BTK occupancy may be monitored in con- 
junction with other enzymatic activities in a multiplexing setting, using either the direct probes in conjunction with ABPs targeting other enzymes and equipped with complementary fluorophores, or by making use of a number of mutually exclusive bioorthogonal ligations.

\section{Experimental}

\section{General}

Tetrahydrofuran (THF) was distilled over $\mathrm{LiAlH}_{4}$ before use. Acetonitrile (ACN), dichloromethane (DCM), N,N-dimethylformamide (DMF), methanol (MeOH) and trifluoroacetic acid (TFA) were of peptide synthesis grade, purchased at Biosolve, and used as received. All general chemicals (Fluka, Acros, Merck, Aldrich, Sigma) were used as received. Traces of water were removed from reagents used in reactions that require anhydrous conditions by coevaporation with toluene. Solvents that were used in reactions were stored over $4 \AA$ molecular sieves, except methanol and acetonitrile, which were stored over $3 \AA$ molecular sieves. Molecular sieves were flame dried before use. Unless noted otherwise all reactions were performed under an argon atmosphere. Column chromatography was performed on Silicycle Silia-P Flash Silica Gel, with a particle size of $40-63 \mu \mathrm{m}$. The eluents toluene and ethyl acetate were distilled prior to use. TLC analysis was conducted on Merck aluminium sheets (Silica gel 60 F254). Compounds were visualized by UV absorption $(254 \mathrm{~nm})$, by spraying with a solution of $\left(\mathrm{NH}_{4}\right)_{6} \mathrm{MO}_{7} \mathrm{O}_{24} \quad 4 \mathrm{H}_{2} \mathrm{O} \quad\left(25 \mathrm{~g} \mathrm{~L}^{-1}\right)$ and $\left(\mathrm{NH}_{4}\right)_{4} \mathrm{Ce}-$ $\left(\mathrm{SO}_{4}\right)_{4} \cdot 2 \mathrm{H}_{2} \mathrm{O}\left(10 \mathrm{~g} \mathrm{~L}^{-1}\right)$ in $10 \%$ sulphuric acid, a solution of $\mathrm{KMnO}_{4}\left(20 \mathrm{~g} \mathrm{~L}^{-1}\right)$ and $\mathrm{K}_{2} \mathrm{CO}_{3}\left(10 \mathrm{~g} \mathrm{~L}^{-1}\right)$ in water, or ninhydrin $\left(0.75 \mathrm{~g} \mathrm{~L}^{-1}\right)$ and acetic acid $\left(12.5 \mathrm{~mL} \mathrm{~L}^{-1}\right)$ in ethanol, where appropriate, followed by charring at ca. $150{ }^{\circ} \mathrm{C} .{ }^{1} \mathrm{H}-$ and ${ }^{13} \mathrm{C}-\mathrm{NMR}$ spectra were recorded on a Bruker DMX-400 $(400 \mathrm{MHz})$ or a Bruker DMX-600 (600 MHz) spectrometer. Chemical shifts are given in $\mathrm{ppm}(\delta)$ relative to tetramethylsilane $\left({ }^{1} \mathrm{H}-\mathrm{NMR}\right)$ or $\mathrm{CDCl}_{3}\left({ }^{13} \mathrm{C}-\mathrm{NMR}\right)$ as internal standard. Mass spectra were recorded on a PE/Sciex API 165 instrument equipped with an Electrospray Interface (ESI) (Perkin-Elmer). High-resolution MS (HRMS) spectra were recorded with a Finnigan LTQ-FT (Thermo Electron). IR spectra were recorded on a Shimadzu FTIR-8300 and absorptions are given in $\mathrm{cm}^{-1}$. Optical rotations $[\alpha]_{\mathrm{D}}^{23}$ were recorded on a Propol automatic polarimeter at room temperature. LC-MS analysis was performed on a Jasco HPLC system with a Phenomenex Gemini $3 \mu \mathrm{m}$ C18 $50 \times 4.6 \mathrm{~mm}$ column (detection simultaneously at 214 and $254 \mathrm{~nm}$ ), coupled to a PE Sciex API 165 mass spectrometer with ESI. HPLC gradients were $10 \rightarrow 90 \%, 0 \rightarrow 50 \%$ or $10 \rightarrow$ $50 \% \mathrm{ACN}$ in $0.1 \% \mathrm{TFA} / \mathrm{H}_{2} \mathrm{O}$. Chiral HPLC analysis was performed on a Spectroflow 757 system (ABI Analytical Kratos Division, detection at $254 \mathrm{~nm}$ ) equipped with a Chiralcel OD column $(150 \times 4.6 \mathrm{~mm})$. The compounds were purified on a Gilson HPLC system coupled to a Phenomenex Gemini $5 \mu \mathrm{m}$ $250 \times 10 \mathrm{~mm}$ column and a GX281 fraction collector. The used gradients were either $0 \rightarrow 30 \%$ or $10 \rightarrow 40 \%$ ACN in $0.1 \%$ TFA/water, depending on the lipophilicity of the product.
Appropriate fractions were pooled, and concentrated in a Christ rotary vacuum concentrator overnight at room temperature at 0.1 mbar.

3-Iodo-1 $H$-pyrazolo[3,4- $\boldsymbol{d}$ ]pyrimidin-4-amine (10). To a solution of 4-aminopyrazolo[3,4- $d]$ pyrimidine $(9,2.50 \mathrm{~g}$, $18.5 \mathrm{mmol}$ ) in DMF $(43 \mathrm{~mL})$ was added $N$-iodosuccinimide (1.5 eq., $6.24 \mathrm{~g}, 27.7 \mathrm{mmol}$ ) and the mixture was heated to $80{ }^{\circ} \mathrm{C}$ overnight, before being cooled to $0{ }^{\circ} \mathrm{C} . \mathrm{H}_{2} \mathrm{O}(110 \mathrm{~mL})$ was added and the mixture was allowed to stand at $0{ }^{\circ} \mathrm{C}$ for $30 \mathrm{~min}$. followed by filtration of the solid. The residue was washed with ice-cold $\mathrm{EtOH}, \mathrm{Et}_{2} \mathrm{O}$ and EtOAc and dried in vacuo. The title compound was obtained without further purification as a pale yellow solid (yield: $4.22 \mathrm{~g}, 16.17 \mathrm{mmol}$, $87 \%) . R_{\mathrm{F}}=0.30(10 \% \mathrm{MeOH}-\mathrm{DCM}) .{ }^{1} \mathrm{H}$ NMR $(400 \mathrm{MHz}$, DMSO- $\left._{6}\right) \delta 13.84(\mathrm{~s}, 1 \mathrm{H}, \mathrm{NH}), 8.17(\mathrm{~s}, 1 \mathrm{H}, \mathrm{CH}) .{ }^{13} \mathrm{C} \mathrm{NMR}$ $\left(101 \mathrm{MHz}, \mathrm{DMSO}-\mathrm{d}_{6}\right) \delta 157.50,155.90,155.0,102.51,89.88$.

3-(4-Phenoxyphenyl)-1 $H$-pyrazolo[3,4- $d]$ pyrimidin-4-amine (11). Compound $10(0.2 \mathrm{~g}, 0.77 \mathrm{mmol}), \mathrm{K}_{3} \mathrm{PO}_{4}(3 \mathrm{eq} ., 0.49 \mathrm{~g}$, $2.30 \mathrm{mmol}$ ), 4-phenoxybenzene boronic acid (3 eq., $0.49 \mathrm{~g}$, $2.29 \mathrm{mmol})$ and $\operatorname{Pd}\left(\mathrm{PPh}_{3}\right)_{4}(0.14$ eq., $0.12 \mathrm{~g}, 0.11 \mathrm{mmol})$ were dissolved in sonicated dioxane $(2.5 \mathrm{~mL})$ in a microwave vial. The resulting mixture was heated to $180{ }^{\circ} \mathrm{C}$ for $10 \mathrm{~min}$. under microwave irradiation. EtOAc $(10 \mathrm{~mL})$ was added and the mixture was washed with $\mathrm{H}_{2} \mathrm{O}$ and brine before being dried over $\mathrm{MgSO}_{4}$, filtered and concentrated under reduced pressure. The title compound was obtained after purification by column chromatography (100\% DCM $\rightarrow 4 \% \mathrm{MeOH}-\mathrm{DCM})$ as a white solid (yield: $0.18 \mathrm{~g}, 0.61 \mathrm{mmol}, 79 \%) . R_{\mathrm{F}}=0.19(5 \% \mathrm{MeOH}-$ DCM). ${ }^{1} \mathrm{H}$ NMR (400 MHz, DMSO-d $\left.\mathrm{d}_{6}\right) \delta 13.58(\mathrm{~s}, 1 \mathrm{H}, \mathrm{NH}), 8.22$ $(\mathrm{s}, 1 \mathrm{H}, \mathrm{CH}), 7.67(\mathrm{~d}, J=8.8 \mathrm{~Hz}, 2 \mathrm{H}, 2 \times \mathrm{CH}), 7.43(\mathrm{t}, J=8.0 \mathrm{~Hz}$, $2 \mathrm{H}, 2 \times \mathrm{CH}), 7.20-7.11(\mathrm{~m}, 5 \mathrm{H}, 5 \times \mathrm{CH}) .{ }^{13} \mathrm{C}$ NMR $(101 \mathrm{MHz}$, DMSO- $\left._{6}\right) \delta 158.11,157.04,156.33,155.82,143.99,130.17$, 128.48, 123.82, 119.05, 96.95. LC-MS analysis: Rt $5.63 \mathrm{~min}$ (linear gradient $10-90 \%$ acetonitrile in $\mathrm{H}_{2} \mathrm{O}, 0.1 \%$ TFA, $15 \mathrm{~min})$. ESI-MS $(\mathrm{m} / \mathrm{z}): 304.07\left[\mathrm{M}+\mathrm{H}^{+}\right]$.

tert-Butyl $(R)$-3-(4-amino-3-(4-phenoxyphenyl)-1H-pyrazolo[3,4-d]pyrimidin-1-yl)piperidine-1-carboxylate (13). To a suspension of (S)-1-Boc-3-hydroxypiperidine 12 (2 eq., 1.24 g, $6.2 \mathrm{mmol}$ ) and polymer-bound triphenylphosphine (3 eq., $3.08 \mathrm{~g}, 9.2 \mathrm{mmol})$ in THF $(20 \mathrm{~mL})$ was added dropwise diisopropyl diazodicarboxylate ( 2 eq., $1.21 \mathrm{~mL}, 6.1 \mathrm{mmol}$ ) and the reaction mixture was stirred for $5 \mathrm{~min}$. Compound $\mathbf{1 1}(0.93 \mathrm{~g}$, $3.08 \mathrm{mmol}$ ) was added and the resulting mixture was heated for $5 \mathrm{~min}$. The suspension was stirred overnight before being filtered over Celite to remove the resins and the resins were washed with $\mathrm{MeOH}$ and DCM. The filtrate was concentrated and the target compound was obtained by column chromatography $(40 \% \rightarrow 55 \%$ EtOAc/Pentane) as a yellow solid (yield: $0.84 \mathrm{~g}, 1.72 \mathrm{mmol}, 56 \%) . R_{\mathrm{F}}=0.50$ (90\% EtOAc/Pentane). ${ }^{1} \mathrm{H}$ NMR $\left(400 \mathrm{MHz}, \mathrm{CDCl}_{3}\right) \delta 8.31(\mathrm{~s}, 1 \mathrm{H}, \mathrm{CH}), 7.65(\mathrm{~d}, J=8.4$ $\mathrm{Hz}, 2 \mathrm{H}, 2 \times \mathrm{CH}), 7.35(\mathrm{t}, J=8.0 \mathrm{~Hz}, 2 \mathrm{H}, 2 \times \mathrm{CH}), 7.15-7.12$ $(\mathrm{m}, 3 \mathrm{H}, 3 \times \mathrm{CH}), 7.06(\mathrm{~d}, J=8.0 \mathrm{~Hz}, 2 \mathrm{H}, 2 \times \mathrm{CH}), 4.90-4.81$ (m, 1H, CH), 4.36-4.19 (m, 1H), 4.12-4.06 (m, 1H), 3.50-3.34 $(\mathrm{m}, 1 \mathrm{H}), 2.86(\mathrm{t}, J=10.8 \mathrm{~Hz}, 1 \mathrm{H}), 2.31-2.16(\mathrm{~m}, 2 \mathrm{H}), 1.93-1.88$ (m, 1H), 1.72-1.67 (m, 1H), $1.44(\mathrm{~s}, 9 \mathrm{H}) .{ }^{13} \mathrm{C}$ NMR $(101 \mathrm{MHz}$, $\left.\mathrm{CDCl}_{3}\right) \delta 158.10,157.97,156.02,154.87,154.30,143.63,130.60$, 
128.50, 124.44, 119.37, 98.09, 79.51, 52.51, 48.20, 44.05, 29.90, 28.95, 24.51. LC-MS analysis: Rt $8.26 \mathrm{~min}$ (linear gradient $10-90 \%$ acetonitrile in $\mathrm{H}_{2} \mathrm{O}, 0.1 \%$ TFA, $\left.15 \mathrm{~min}\right)$. ESI-MS $(\mathrm{m} / \mathrm{z})$ : $487.13\left[\mathrm{M}+\mathrm{H}^{+}\right]$.

(R)-3-(4-Phenoxyphenyl)-1-(piperidin-3-yl)-1H-pyrazolo[3,4- $d]$ pyrimidin-4-amine (14). Compound 13 (0.05 g, $0.1 \mathrm{mmol})$ was stirred in $4.0 \mathrm{M} \mathrm{HCl}$ in dioxane $(1 \mathrm{~mL})$ for $2 \mathrm{~h}$. The reaction mixture was concentrated in vacuo and the residue was suspended in EtOAc before being filtered. The residue was washed with EtOAc and dried under reduced pressure. The title compound was obtained without further purification as a white solid (yield: $0.042 \mathrm{~g}, 0.1 \mathrm{mmol}, 100 \%) . R_{\mathrm{F}}=0.05(90 \%$ EtOAc/Pentane). LC-MS analysis: Rt 5.34 min (linear gradient 10-90\% acetonitrile in $\mathrm{H}_{2} \mathrm{O}, 0.1 \%$ TFA, $\left.15 \mathrm{~min}\right)$. ESI-MS $(\mathrm{m} / \mathrm{z})$ : $387.01\left[\mathrm{M}+\mathrm{H}^{+}\right]$.

Ibrutinib (1). To a solution of crude amine $14(0.20 \mathrm{mmol})$ in DCM ( $1 \mathrm{~mL})$ were added TEA (3.0 eq., $84 \mu \mathrm{L}, 0.6 \mathrm{mmol})$ and acryloyl chloride (1.3 eq., $20 \mu \mathrm{L}, 0.26 \mathrm{mmol})$. The resulting mixture was stirred overnight prior to washing with aqueous solution of citric acid $(5 \%, 5 \mathrm{~mL})$ and brine. The title compound was obtained after RP-HPLC purification (linear gradient $40 \% \rightarrow 60 \%$ ACN in $\mathrm{H}_{2} \mathrm{O}, 0.1 \% \mathrm{TFA}, 15 \mathrm{~min}$ ) as a white solid (yield: $12.0 \mathrm{mg}, 92.0 \mu \mathrm{mol}, 46 \%) .{ }^{1} \mathrm{H}$ NMR $(600 \mathrm{MHz}$, DMSO-d $\left._{6}\right): \delta 8.42(\mathrm{~s}, 1 \mathrm{H}), 7.67(\mathrm{~d}, J=7.2 \mathrm{~Hz}, 2 \mathrm{H}), 7.44(\mathrm{t}, J=$ $7.2 \mathrm{~Hz}, 2 \mathrm{H}), 7.19(\mathrm{t}, J=7.2 \mathrm{~Hz}, 1 \mathrm{H}), 7.16(\mathrm{~d}, J=9.0 \mathrm{~Hz}, 2 \mathrm{H})$, $7.13(\mathrm{~d}, J=9.0 \mathrm{~Hz}, 2 \mathrm{H}), 6.85(\mathrm{t}, J=13.2,0.5 \mathrm{H}), 6.69(\mathrm{t}, J=$ $15.6 \mathrm{~Hz}, 0.5 \mathrm{H}), 6.13(\mathrm{~d}, J=16.2 \mathrm{~Hz}, 0.5 \mathrm{H}), 6.06(\mathrm{~d}, J=16.8 \mathrm{~Hz}$, $0.5 \mathrm{H}), 5.70(\mathrm{~d}, J=10.2 \mathrm{~Hz}, 0.5 \mathrm{H}), 5.59$ (d, $J=9.6 \mathrm{~Hz}, 0.5 \mathrm{H})$, 4.79-4.71 (m, 1H), 4.56 (d, $J=10.8 \mathrm{~Hz}, 1 \mathrm{H}), 4.19$ (br s, 1H), $4.06(\mathrm{~d}, J=13.2 \mathrm{~Hz}, 0.5 \mathrm{H}), 3.71(\mathrm{t}, J=10.8 \mathrm{~Hz}, 0.5 \mathrm{H}), 3.26-3.19$ $(\mathrm{m}, 1 \mathrm{H}), 3.04(\mathrm{t}, J=12.0 \mathrm{~Hz}, 0.5 \mathrm{H}), 2.30-2.23(\mathrm{~m}, 1 \mathrm{H})$, 2.15-2.13 (m, 1H), 1.95-1.92 (m, 1H), 1.66-1.54 (m, 1H). ${ }^{13} \mathrm{C}$ NMR (150 MHz, DMSO-d $\left.\mathrm{d}_{6}\right): \delta$ 164.64, 157.48, 156.15, $152.66,144.73,130.11,128.28,127.49,127.21,126.95,126.12$, 123.86, 119.02, 115.76, 97.06, 53.03, 52.41, 49.220, 45.65, 45.12, 41.54, 29.49, 29.27, 24.74, 23.13. IR film ( $\left.\mathrm{cm}^{-1}\right): 2936.8$, 1688.8, 1609.7, 1586.58, 1516.1, 1489.1, 1436.1, 1233.5, 1197.9, 1134.2, 856.9, 801.6, 759.6, 725.3, 698.6. HRMS: calcd for $\mathrm{C}_{25} \mathrm{H}_{24} \mathrm{~N}_{6} \mathrm{O}_{2}\left[\mathrm{M}+\mathrm{H}^{+}\right]:$441.20335; found: 441.20315.

tert-Butyl (2-(piperazin-1-yl)ethyl)carbamate (16). 1-(2Aminoethyl)piperazine (15, $32.8 \mathrm{~mL}, 250 \mathrm{mmol})$ and benzaldehyde (1 eq., $25.5 \mathrm{~mL}, 250 \mathrm{mmol}$ ) were dissolved in toluene $(200 \mathrm{~mL})$ and the reaction mixture was refluxed over a DeanStark apparatus in $3 \mathrm{~h}$, cooled to $0{ }^{\circ} \mathrm{C}$, and treated with dropwise addition of benzylchloroformate (1 eq., $38 \mathrm{~mL}$, $250 \mathrm{mmol}$ ). The resulting mixture was stirred overnight before being concentrated. The residue was dissolved in $\mathrm{MeOH}$ $(500 \mathrm{~mL})$, cooled to $0{ }^{\circ} \mathrm{C}$ and treated with $2 \mathrm{NHCl}(125 \mathrm{~mL})$. The resulting mixture ( $\mathrm{pH} 1-2)$ was allowed to warm up to RT and concentrated under reduced pressure. The aqueous layer was washed with DCM before being made basic with $\mathrm{NH}_{4} \mathrm{OH}$ $(\mathrm{pH}=10)$ and extracted with DCM $(3 \times)$, washed with brine, dried, filtered and evaporated. The residue was applied to silica column chromatography $(4 \% \rightarrow 6 \% \mathrm{MeOH}-\mathrm{DCM}+1 \%$ TEA) to afford benzyl 4-(2-aminoethyl)piperazine-1-carboxylate as a yellowish oil (yield: $25.15 \mathrm{~g}, 95.5 \mathrm{mmol}, 38 \%$ ). $R_{\mathrm{F}}=0.20$
(20\% MeOH-DCM). ${ }^{1} \mathrm{H}$ NMR (400 MHz, $\left.\mathrm{CDCl}_{3}\right) \delta 7.36-7.28(\mathrm{~m}$, $\left.5 \mathrm{H}, \mathrm{CH}_{\mathrm{ar}}\right), 5.12\left(\mathrm{~s}, 2 \mathrm{H}, \mathrm{CH}_{2}\right), 3.51\left(\mathrm{t}, J=4.8 \mathrm{~Hz}, 4 \mathrm{H}, 2 \times \mathrm{CH}_{2}\right)$, $2.79\left(\mathrm{t}, J=6.0 \mathrm{~Hz}, 2 \mathrm{H}, \mathrm{CH}_{2}\right), 2.44\left(\mathrm{t}, J=6.0 \mathrm{~Hz}, 2 \mathrm{H}, \mathrm{CH}_{2}\right), 2.40$ (br s, 4H, $\left.2 \times \mathrm{CH}_{2}\right), 2.30\left(\mathrm{~s}, 2 \mathrm{H}, \mathrm{NH}_{2}\right) \cdot{ }^{13} \mathrm{C} \mathrm{NMR}(101 \mathrm{MHz}$, $\left.\mathrm{CDCl}_{3}\right) \delta 154.76,136.32,128.09,127.59,127.44,67.10,60.06$, $52.48,43.42,38.03$. After the solution of the carboxylate product (12.58 $\mathrm{g}, 47.75 \mathrm{mmol}$ ) in THF (200 $\mathrm{mL}$ ) was cooled to $0{ }^{\circ} \mathrm{C}$, Boc $_{2} \mathrm{O}$ (1.2 eq., $12.51 \mathrm{~g}, 57.30 \mathrm{mmol}$ ) was added portion wise and the reaction mixture was allowed to warm up to RT overnight before being concentrated. The residue was further purified by silica column chromatography $(20 \% \rightarrow 30 \%$ EtOAc/ Pentane) to afford benzyl 4-(2-((tert-butoxycarbonyl)amino)ethyl)piperazine-1-carboxylate as a yellowish oil (13.71 g, $37.72 \mathrm{mmol}, 79 \%) . R_{\mathrm{F}}=0.30$ (80\% EtOAc/Pentane). ${ }^{1} \mathrm{H}$ NMR $\left(400 \mathrm{MHz}, \mathrm{CDCl}_{3}\right) \delta 7.37-7.30\left(\mathrm{~m}, 5 \mathrm{H}, \mathrm{CH}_{\mathrm{ar}}\right), 5.13\left(\mathrm{~s}, 2 \mathrm{H}, \mathrm{CH}_{2}\right)$, 4.98 (br s, $1 \mathrm{H}, \mathrm{NH}$ ), 3.51 (t, $J=5.2 \mathrm{~Hz}, 4 \mathrm{H}, 2 \times \mathrm{CH}_{2}$ ), 3.25-3.21 $\left(\mathrm{m}, 2 \mathrm{H}, \mathrm{CH}_{2}\right), 2.46\left(\mathrm{t}, J=6.0 \mathrm{~Hz}, 2 \mathrm{H}, \mathrm{CH}_{2}\right), 2.41$ (br s, $4 \mathrm{H}, 2 \times$ $\left.\mathrm{CH}_{2}\right) .{ }^{13} \mathrm{C} \mathrm{NMR}\left(101 \mathrm{MHz}, \mathrm{CDCl}_{3}\right) \delta 155.85,155.11,136.59$, 128.42, 127.96, 127.82, 79.17, 67.05, 57.14, 52.53, 43.67, 36.93, 28.35. HRMS: calcd for $\mathrm{C}_{19} \mathrm{H}_{29} \mathrm{~N}_{3} \mathrm{O}_{4}\left[\mathrm{M}+\mathrm{H}^{+}\right]$: 364.21581; found: 364.20315 . To a solution of $4-(2-(($ tert-butoxycarbonyl)amino)ethyl)piperazine-1-carboxylate $(1.82 \mathrm{~g}, 5.0 \mathrm{mmol})$ in $\mathrm{MeOH}(20 \mathrm{~mL}) \mathrm{Pd} / \mathrm{C}(10 \% \mathrm{w} / \mathrm{w}, 150 \mathrm{mg})$ was added. Hydrogen gas was then bubbled through the mixture overnight. The reaction mixture was filtered over Celite and concentrated to obtain the target compound as a yellowish oil (yield: $1.08 \mathrm{~g}$, $4.71 \mathrm{mmol}, 94 \%)$. The target compound was used without further purification. $R_{\mathrm{F}}=0.29\left(1 / 1 / 1 \mathrm{v} / \mathrm{v} / \mathrm{v} \mathrm{H}_{2} \mathrm{O}-\mathrm{ACN}-t \mathrm{BuOH}\right)$. ${ }^{1} \mathrm{H}$ NMR (400 MHz, MeOD) $\delta 3.80-3.65\left(\mathrm{~m}, 6 \mathrm{H}, 3 \times \mathrm{CH}_{2}\right.$ ), 3.57-3.51 (m, 4H, $\left.2 \times \mathrm{CH}_{2}\right), 3.38\left(\mathrm{t}, J=7.6 \mathrm{~Hz}, 2 \mathrm{H}, \mathrm{CH}_{2}\right)$, $1.46\left(\mathrm{~s}, 9 \mathrm{H}, 3 \times \mathrm{CH}_{3}\right) \cdot{ }^{13} \mathrm{C} \mathrm{NMR}(101 \mathrm{MHz}, \mathrm{MeOD}) \delta$ 158.03, 80.43, 57.74, 54.59, 53.30, 49.87, 41.93, 36.11, 35.09, 28.67. HRMS: calcd for $\mathrm{C}_{11} \mathrm{H}_{23} \mathrm{~N}_{3} \mathrm{O}_{2}\left[\mathrm{M}+\mathrm{H}^{+}\right]$: 230.17903; found: 230.17907.

(E)-4-bromobut-2-enoic acid (17). To a solution of commercially available crotonic acid $(10 \mathrm{~g}, 116 \mathrm{mmol})$ in benzene (150 mL) was added $N$-bromosuccinimide (1.1 eq., $22.74 \mathrm{~g}$, $120 \mathrm{mmol}$ ) and benzoyl peroxide (0.01 eq, $0.45 \mathrm{~g}, 1.4 \mathrm{mmol}$ ) and the resulting mixture was refluxed for $4 \mathrm{~h}$. The reaction mixture was then allowed to cool to $0{ }^{\circ} \mathrm{C}$, which resulted in precipitation of succinimide crystals. The crystals were filtered over Celite and washed with toluene. The filtrate was concentrated and the residue was recrystallized from hexanes yielding the title compound as a pale yellow solid (yield: $9.55 \mathrm{~g}$, $57.9 \mathrm{mmol}, 50 \%) . R_{\mathrm{F}}=0.79\left(1 / 1 / 1 \mathrm{v} / \mathrm{v} / \mathrm{v} \mathrm{H} \mathrm{H}_{2} \mathrm{O}-\mathrm{ACN}-t \mathrm{BuOH}\right)$. ${ }^{1} \mathrm{H}$ NMR (400 MHz, $\left.\mathrm{CDCl}_{3}\right) \delta 9.04(\mathrm{bs}, 1 \mathrm{H}), 7.12(\mathrm{~m}, 1 \mathrm{H}), 6.05$ $(\mathrm{d}, J=15.2 \mathrm{~Hz}, 1 \mathrm{H}), 4.04\left(\mathrm{dd}, J_{1}=1.2 \mathrm{~Hz}, J_{2}=7.2 \mathrm{~Hz}, 2 \mathrm{H}\right)$. ${ }^{13} \mathrm{C} \mathrm{NMR}\left(101 \mathrm{MHz}, \mathrm{CDCl}_{3}\right) \delta 170.41,144.20,123.79,28.72$.

(E)-4-(4-(2-((tert-Butoxycarbonyl)amino)ethyl)piperazin-1-yl)but-2-enoic acid (18). Compound 17 (1 eq., 0.22 g, $1 \mathrm{mmol}$ ) was dissolved in THF $(5 \mathrm{~mL})$. A solution of compound 16 $(0.27 \mathrm{~g}, 1 \mathrm{mmol})$ and TEA ( 3 eq., $0.42 \mathrm{~mL}, 3.0 \mathrm{mmol})$ in THF ( $2 \mathrm{~mL}$ ) was added and the mixture was stirred overnight and concentrated under reduced pressure. The title compound was used without further purification. $R_{\mathrm{F}}=0.29\left(1 / 1 / 1 \mathrm{v} / \mathrm{v} / \mathrm{v} \mathrm{H}_{2} \mathrm{O}-\right.$ $\mathrm{ACN}-t \mathrm{BuOH}$ ). LC-MS analysis: Rt $5.69 \mathrm{~min}$ (linear gradient 
0-50\% acetonitrile in $\mathrm{H}_{2} \mathrm{O}, 0.1 \%$ TFA, $\left.15 \mathrm{~min}\right)$. ESI-MS $(\mathrm{m} / \mathrm{z})$ : $313.93\left[\mathrm{M}+\mathrm{H}^{+}\right]$.

tert-Butyl (R,E)-(2-(4-(4-(3-(4-amino-3-(4-phenoxyphenyl)-1Hpyrazolo[3,4- $d]$ pyrimidin-1-yl)piperidin-1-yl)-4-oxobut-2-en1-yl)piperazin-1-yl)ethyl)carbamate (19). HATU (2.2 eq., 1.25 g, $3.3 \mathrm{mmol}$ ) was added to a solution of compound 18 (4 eq., $1.88 \mathrm{~g}, 6.0 \mathrm{mmol}$ ) and TEA (7 eq., $1.46 \mathrm{~mL}, 10.5 \mathrm{mmol}$ ) in DMF $(5 \mathrm{~mL})$ and the reaction mixture was allowed to stir for $1 \mathrm{~min}$. A solution of amine $14(0.63 \mathrm{~g}, 1.5 \mathrm{mmol})$ in DMF $(2 \mathrm{~mL})$ was added and the resulting mixture was stirred overnight. EtOAc $(25 \mathrm{~mL})$ was added and the organic layer was washed with sat. aq. $\mathrm{NaHCO}_{3}$ and brine, dried over $\mathrm{MgSO}_{4}$, filtered and concentrated in vacuo. The title compound was obtained after column chromatography $(4 \% \rightarrow 8 \% \mathrm{MeOH}-$ DCM) as a brown solid (yield: $0.89 \mathrm{~g}, 1.31 \mathrm{mmol}, 87 \%$ ). $R_{\mathrm{F}}=$ 0.55 (10\% MeOH-DCM). ${ }^{1} \mathrm{H}$ NMR (400 MHz, DMSO-d 6 ) $\delta 8.26$ $(\mathrm{s}, 1 \mathrm{H}), 7.68(\mathrm{~d}, J=8.8 \mathrm{~Hz}, 2 \mathrm{H}), 7.42(\mathrm{t}, J=7.6 \mathrm{~Hz}, 2 \mathrm{H})$, 7.20-7.11 (m, 5H), $6.52(\mathrm{t}, J=9.8 \mathrm{~Hz}, 1 \mathrm{H}), 6.48-6.42(\mathrm{~m}, 2 \mathrm{H})$, 5.88 (br s, $1 \mathrm{H}), 4.78-4.72(\mathrm{~m}, 1 \mathrm{H}), 4.33(\mathrm{~d}, J=12.0 \mathrm{~Hz}, 1 \mathrm{H})$, 4.01 (dt, $J=16,8 \mathrm{~Hz}, 1 \mathrm{H}), 3.60-3.57(\mathrm{~m}, 1 \mathrm{H}), 3.51(\mathrm{t}, J=12 \mathrm{~Hz}$, $1 \mathrm{H}), 3.27-3.18(\mathrm{~m}, 1 \mathrm{H}), 3.10-3.04(\mathrm{~m}, 6 \mathrm{H}), 2.42-2.37(\mathrm{~m}, 6 \mathrm{H})$, 2.21-2.17 (m, 1H), 2.03-1.96 (m, 1H), 1.70-1.59 (m, 1H), 1.41 (s, 9H). ${ }^{13} \mathrm{C}$ NMR (101 MHz, DMSO-d 6$) \delta 164.36,157.69$, 156.91, 154.96, 153.82, 142.61, 139.95, 129.39, 127.66, 123.12, 122.37, 118.42, 97.38, 77.08, 57.99, 56.64, 52.32, 52.07, 47.51, 42.81, 37.39, 28.57, 27.73, 23.18. HRMS: calcd for $\mathrm{C}_{37} \mathrm{H}_{47} \mathrm{~N}_{9} \mathrm{O}_{4}$ $\left[\mathrm{M}+\mathrm{H}^{+}\right]$: 682.37510; found: 682.37513. LC-MS analysis: Rt $6.05 \mathrm{~min}$ (linear gradient $10-90 \%$ acetonitrile in $\mathrm{H}_{2} \mathrm{O}, 0.1 \%$ TFA, $15 \mathrm{~min})$. ESI-MS (m/z): $682.13\left[\mathrm{M}+\mathrm{H}^{+}\right]$.

$(R, E)-1-(3-(4-A m i n o-3-(4-p h e n o x y p h e n y l)-1 H$-pyrazolo[3,4- $d]$ pyrimidin-1-yl)piperidin-1-yl)-4-(4-(2-aminoethyl)piperazin-1yl)but-2-en-1-one (20). Compound 19 (0.015 g, $0.022 \mathrm{mmol})$ was stirred in $4.0 \mathrm{M} \mathrm{HCl}$ in dioxane $(2 \mathrm{~mL})$ for $2 \mathrm{~h}$. The reaction mixture was concentrated in vacuo and the residue was suspended in EtOAc before being filtered. The residue was washed with EtOAc and dried under reduced pressure. The title compound was obtained without further purification as a white solid (yield: $0.013 \mathrm{~g}, 0.022 \mathrm{mmol}, 100 \%) . R_{\mathrm{F}}=0.05(90 \%$ EtOAc/Pentane). LC-MS analysis: Rt $5.26 \mathrm{~min}$ (linear gradient $10-90 \%$ acetonitrile in $\mathrm{H}_{2} \mathrm{O}, 0.1 \%$ TFA, $\left.15 \mathrm{~min}\right)$. ESI-MS $(\mathrm{m} / \mathrm{z})$ : $587.27\left[\mathrm{M}+\mathrm{H}^{+}\right]$.

$(R, E)-N$-(2-(4-(4-(3-(4-Amino-3-(4-phenoxyphenyl)-1H-pyrazolo[3,4- $d]$ pyrimidin-1-yl)piperidin-1-yl)-4-oxobut-2-en-1-yl)piperazin1-yl)ethyl)-3-(5,5-difluoro-1,3,7,9-tetramethyl-5 $\mathrm{H}$-514,614-dipyrrolo$\left[1,2-c: 2^{\prime}, 1^{\prime}-f\right][1,3,2]$ diazaborinin-2-yl)propanamide (4).

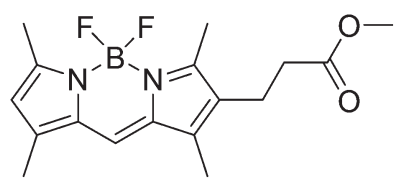

Carboxaldehyde pyrrole $^{16}$ (90 mg, $0.43 \mathrm{mmol}, 1$ eq.) was dissolved in $\mathrm{MeOH}(5 \mathrm{~mL})$ and 2,4-dimethylpyrrole $(41 \mathrm{mg}, 44 \mu \mathrm{L}$, $0.43 \mathrm{mmol}, 1$ eq.) was added. The resulting mixture was cooled to $0{ }^{\circ} \mathrm{C}$, and hydrobromic acid, $48 \%$ solution in water (0.072 mL, $0.64 \mathrm{mmol}, 1.5$ eq.) was added. After $2 \mathrm{~h}$ of stirring a yellowish precipitate formed and TLC analysis showed complete consumption of the starting materials. The crude dipyrrole $\mathrm{HBr}$ salt was concentrated and coevaporated with DCE $(3 \times)$ and dissolved in DCE $(10 \mathrm{~mL})$ under an argon atmosphere. Triethylamine $(0.178 \mathrm{~mL}, 1.29 \mathrm{mmol}, 3$ eq. $)$ and $\mathrm{BF}_{3} \cdot \mathrm{Et}_{2} \mathrm{O}$ (0.57 mL, $2.15 \mathrm{mmol}, 5$ eq.) were added, and the reaction was subsequently stirred at room temperature until TLC showed completion of the reaction. The solution was concentrated and the product purified by silica gel column chromatography $(0 \% \rightarrow 2 \%$ EtOAc in toluene) which gave 4,4 -difluoro1,3,7,9-tetramethyl-2-(2-(ethoxycarbonylmethyl))-4-bora-3a,4adiaza- $s$-indacene (106 mg, $0.32 \mathrm{mmol}, 74 \%) . R_{\mathrm{f}}=0.4$ (6:1 toluene-EtOAc). ${ }^{1} \mathrm{H}-\mathrm{NMR}\left(400 \mathrm{MHz}, \mathrm{CDCl}_{3}\right) \delta 6.99(\mathrm{~s}, 1 \mathrm{H}), 6.00$ $(\mathrm{s}, 1 \mathrm{H}), 3.66(\mathrm{~s}, 3 \mathrm{H}), 2.70(\mathrm{t}, J=7.8 \mathrm{~Hz}, 2 \mathrm{H}), 2.50(\mathrm{~s}, 6 \mathrm{H}), 2.43$ $(\mathrm{t}, J=7.8,2 \mathrm{H}), 2.18(\mathrm{~d}, J=15.4,6 \mathrm{H}) .{ }^{13} \mathrm{C}-\mathrm{NMR}(101 \mathrm{MHz}$, $\left.\mathrm{CDCl}_{3}\right) \delta 173.41,156.51,155.86,141.20,138.54,133.59,133.07$, 128.61, 120.05, 119.08, 77.80, 77.48, 77.16, 52.04, 34.45, 19.86, 14.96, 13.03, 11.56, 9.87. LC-MS analysis $(10 \% \rightarrow 90 \%$ ACN) Rt: $9.18 \mathrm{~min}, \mathrm{ESI}-\mathrm{MS}(\mathrm{m} / \mathrm{z}):[\mathrm{M}+\mathrm{H}]^{+}: 335.0 ;[\mathrm{M}-\mathrm{F}]^{+}: 315.2$

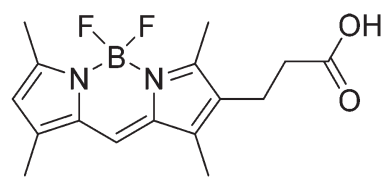

4,4-Difluoro-1,3,7,9-tetramethyl-2-(2-(ethoxycarbonylmethyl))4-bora-3a,4a-diaza-s-indacene (106 $\mathrm{mg}, 0.32 \mathrm{mmol})$ was dissolved in $\mathrm{MeOH}(20 \mathrm{~mL})$ and aq. $\mathrm{NaOH}$ (3.68 mL, $0.1 \mathrm{M}, 1.15$ eq., $0.37 \mathrm{mmol}$ ) was added. The mixture was heated to reflux for $1.5 \mathrm{~h}$, after which by-product formation started to occur. The reaction was quenched by the addition of aq. $\mathrm{HCl}$ (3.68 mL, 0.1 M, 1.15 eq.), followed by extraction with EtOAc $(3 \times)$. The organic layers were dried $\left(\mathrm{MgSO}_{4}\right)$, concentrated and 4,4-difluoro-1,3,7,9-tetramethyl-2-(2-(carboxyethyl))-4-bora3a,4a-diaza-s-indacene was obtained by silica column chromatography $(0 \rightarrow 1 \%$ EtOAc in toluene (starting material) $\rightarrow 1 \%$ EtOAc in toluene $+1 \% \mathrm{AcOH}$ (product)) as a red powder (65 mg, $0.2 \mathrm{mmol}$, 64\% (74\% based on recovered starting material)). $R_{\mathrm{f}}=0.2(6: 1$ toluene-EtOAc $+\mathrm{AcOH}) \cdot \lambda_{\mathrm{abs}} 514 \mathrm{~nm} /$ $\lambda_{\mathrm{em}} 523 \mathrm{~nm}(\mathrm{MeOH}) .{ }^{1} \mathrm{H}-\mathrm{NMR}\left(400 \mathrm{MHz}, \mathrm{CDCl}_{3}\right) \delta 7.01(\mathrm{~s}, 1 \mathrm{H})$, $6.02(\mathrm{~s}, 1 \mathrm{H}), 2.72(\mathrm{t}, J=7.7 \mathrm{~Hz}, 2 \mathrm{H}), 2.56-2.40(\mathrm{~m}, 8 \mathrm{H}), 2.21$ $(\mathrm{d}, J=14.7 \mathrm{~Hz}, 6 \mathrm{H}) .{ }^{13} \mathrm{C}-\mathrm{NMR}\left(101 \mathrm{MHz}, \mathrm{CDCl}_{3}\right) \delta 178.68$, 156.57, 155.48, 141.10, 138.22, 133.42, 132.77, 127.97, 119.84, 118.95, 34.16, 19.37, 14.76, 12.81, 11.36, 9.69. LC-MS analysis $\left(10 \% \rightarrow 90 \%\right.$ ACN) Rt: $7.94 \mathrm{~min}$, ESI-MS $(\mathrm{m} / \mathrm{z}):[\mathrm{M}+\mathrm{H}]^{+}:$ 320.93; [M - F $]^{+}: 301.13$.

HATU (1.3 eq., $49 \mathrm{mg}, 0.13 \mathrm{mmol}$ ) was added to a solution of compound 4,4-difluoro-1,3,7,9-tetramethyl-2-(2-(carboxyethyl))-4-bora-3a,4a-diaza-s-indacene (2 eq., $64 \mathrm{mg}, 0.20 \mathrm{mmol}$ ) and TEA (5 eq., $70 \mu \mathrm{L}, 0.5 \mathrm{mmol})$ in DMF $(0.4 \mathrm{~mL})$ and the reaction mixture was allowed to stir for $1 \mathrm{~min}$. A solution of amine 20 (42 mg, $0.1 \mathrm{mmol})$ in DMF $(0.3 \mathrm{~mL})$ was added and the resulting mixture was stirred overnight. EtOAc $(10 \mathrm{~mL})$ was added and the organic layer was washed with sat. aq. $\mathrm{NaHCO}_{3}$ and brine, dried over $\mathrm{MgSO}_{4}$, filtered and concentrated under reduced pressure. The title compound was obtained after 
RP-HPLC purification (linear gradient $40 \% \rightarrow 60 \% \mathrm{ACN}$ in $\mathrm{H}_{2} \mathrm{O}, 0.1 \%$ TFA, $15 \mathrm{~min}$ ) as a red/brown solid (yield: $15.60 \mathrm{mg}$, $16.51 \mu \mathrm{mol}, 16.5 \%) . R_{\mathrm{F}}=0.05$ (90\% EtOAc/Pentane). ${ }^{1} \mathrm{H}$ NMR $\left(600 \mathrm{MHz}, \mathrm{DMSO}-\mathrm{d}_{6}\right): \delta 8.38(\mathrm{~s}, 1 \mathrm{H}), 8.10(\mathrm{br} \mathrm{s}, 1 \mathrm{H}), 7.66(\mathrm{t}, J=$ $7.8 \mathrm{~Hz}, 2 \mathrm{H}), 7.61(\mathrm{~s}, 1 \mathrm{H}), 7.44(\mathrm{t}, J=7.2 \mathrm{~Hz}, 2 \mathrm{H}), 7.19(\mathrm{t}, J=7.2$ $\mathrm{Hz}, 1 \mathrm{H}), 7.17$ (d, $J=8.4 \mathrm{~Hz}, 2 \mathrm{H}), 7.13$ (d, $J=7.8 \mathrm{~Hz}, 2 \mathrm{H}), 6.84$ $(\mathrm{d}, J=15.0 \mathrm{~Hz}, 0.5 \mathrm{H}), 6.69(\mathrm{~d}, J=15.0 \mathrm{~Hz}), 6.62-6.58(\mathrm{~m}, 0.5 \mathrm{H})$, $6.55-6.52(\mathrm{~m}, 0.5 \mathrm{H}), 6.15(\mathrm{~s}, 1 \mathrm{H}), 4.76-4.66(\mathrm{~m}, 1 \mathrm{H}), 4.57(\mathrm{~d}, J=$ $11.4 \mathrm{~Hz}, 1 \mathrm{H}), 4.20-4.19$ (m, 2H), 4.06 (d, $J=12.6 \mathrm{~Hz}, 1 \mathrm{H}), 3.77$ (t, $J=12 \mathrm{~Hz}, 1 \mathrm{H}), 3.53$ (br s, $1 \mathrm{H}), 3.40$ (br s, 1H), 3.37-3.32 (m, $4 \mathrm{H}), 3.24-3.21(\mathrm{~m}, 2 \mathrm{H}), 3.04(\mathrm{~m}, 1 \mathrm{H}), 2.98-2.88(\mathrm{~m}, 4 \mathrm{H})$, 2.61-2.60 (m, 2H), $2.42(\mathrm{~s}, 3 \mathrm{H}), 2.40(\mathrm{~s}, 1 \mathrm{H}), 2.25(\mathrm{~s}, 6 \mathrm{H}), 2.22$ (s, 3H), 2.14-2.12 (m, 1H), 1.95-1.93 (m, 1H), 1.63-1.56 (m, 1H). ${ }^{13} \mathrm{C}$ NMR (150 MHz, DMSO-d ${ }_{6}$ ): $\delta$ 172.0, 163.79, 158.79, 158.56, 157.40, 156.76, 156.24, 155.70, 154.55, 153.38, 153.07, $144.43,144.03,140.94,139.24,132.43,130.09,129.22,127.24$, $126.87,123.90,121.47,119.04,118.45,117.45,97.22,56.69$, $55.02,52.96,52.32,50.16,49.32,45.77,45.21,41.63,35.16$, $34.13,29.47,24.88,23.25,19.57,14.21,12.51,10.96,9.25$. IR film $\left(\mathrm{cm}^{-1}\right):$ 1670.4, 1603.9, $1517.1 \mathrm{~m} \mathrm{1471.8,} \mathrm{1436.1,} \mathrm{1227.7,}$ 1199.8, 1131.3, 974.1, 832.3, 799.5, 720.4, 666.4. HRMS: calcd for $\mathrm{C}_{48} \mathrm{H}_{56} \mathrm{BF}_{2} \mathrm{~N}_{11} \mathrm{O}_{3}\left[\mathrm{M}+2 \mathrm{H}^{2+}\right]$ : 442.73912; found: 442.73849 .

Ibrutinib-BODIPY-TMR (5). DiPEA (3.5 eq., $60 \mu \mathrm{L}$, $0.35 \mathrm{mmol})$ and BODIPY-TMR-OSu ${ }^{17}(2.2$ eq., $0.11 \mathrm{~g}$, $0.22 \mathrm{mmol}$ ) were added to a solution of crude amine 20 (42 mg, $0.1 \mathrm{mmol})$ in DMF $(0.5 \mathrm{~mL})$. The reaction mixture was stirred overnight before being evaporated. The title compound was obtained after RP-HPLC purification (linear gradient 40\% $\rightarrow 60 \%$ ACN in $\mathrm{H}_{2} \mathrm{O}, 0.1 \%$ TFA, $15 \mathrm{~min}$ ) as a purple solid (yield: $12.19 \mathrm{mg}, 10.25 \mu \mathrm{mol}, 10.3 \%) . R_{\mathrm{F}}=0.05$ (90\% EtOAc/ Pentane). ${ }^{1} \mathrm{H}$ NMR (600 MHz, DMSO-d ${ }_{6}$ ): $\delta 8.26(\mathrm{~s}, 1 \mathrm{H}), 7.85(\mathrm{~d}$, $J=6.6 \mathrm{~Hz}, 2 \mathrm{H}), 7.66(\mathrm{~d}, J=7.8 \mathrm{~Hz}, 3 \mathrm{H}), 7.43(\mathrm{t}, J=10.8 \mathrm{~Hz}$, $2 \mathrm{H}), 7.19$ (t, $J=7.2 \mathrm{~Hz}, 1 \mathrm{H}), 7.16-7.11(\mathrm{~m}, 5 \mathrm{H}), 7.02(\mathrm{~d}, J=7.8$ $\mathrm{Hz}, 2 \mathrm{H}), 6.69$ (br s, 1H), 6.61-6.58 (m, 1H), 6.5 (br s, 1H), 4.73-4.67 (m, 1H), 4.54 (d, $J=11.4 \mathrm{~Hz}, 1 \mathrm{H}), 4.14$ (d, $J=10.2$ $\mathrm{Hz}, 1 \mathrm{H}), 4.03$ (d, $J=11.4 \mathrm{~Hz}, 1 \mathrm{H}), 3.82(\mathrm{~s}, 3 \mathrm{H}), 3.76-3.72(\mathrm{~m}$, $1 \mathrm{H}), 3.24-3.19(\mathrm{~m}, 3 \mathrm{H}), 3.09$ (q, $J=7.8 \mathrm{~Hz}, J=15.0 \mathrm{~Hz}, 4 \mathrm{H})$, 2.66-2.61 (m, 3H), 2.55-2.54 (m, 2H), $2.49(\mathrm{~s}, 3 \mathrm{H}), 2.26(\mathrm{~d}, J=$ $6.6 \mathrm{~Hz}, 3 \mathrm{H}), 2.22(\mathrm{~s}, 3 \mathrm{H}), 2.12(\mathrm{~d}, J=10.2 \mathrm{~Hz}, 1 \mathrm{H}), 1.96-1.89$ $(\mathrm{m}, 1 \mathrm{H}), 1.63-1.52(\mathrm{~m}, 1 \mathrm{H}), 1.18(\mathrm{t}, J=7.2 \mathrm{~Hz}, 4 \mathrm{H}) .{ }^{13} \mathrm{C} \mathrm{NMR}$ $\left(150 \mathrm{MHz}, \mathrm{DMSO}-\mathrm{d}_{6}\right): \delta 159.97,158.18,157.14,156.28,155.66$, 153.96, 143.34, 143.20, 140.58, 134.68, 133.92, 131.07, 130.39, $130.12,128.30,127.89,124.90,124.19,123.80,118.97$, 117.98, 113.78, 97.39, 55.71, 45.76, 40.06, 34.93, 19.80, 12.90, 9.25, 8.59. IR film $\left(\mathrm{cm}^{-1}\right): 1672.3,1604.8,1523.8,1464.0$, 1234.4, 1201.7, 1180.4, 1139.9, 1045.4. HRMS: calcd for $\mathrm{C}_{53} \mathrm{H}_{58} \mathrm{BF}_{2} \mathrm{~N}_{11} \mathrm{O}_{4}\left[\mathrm{M}+2 \mathrm{H}^{2+}\right]$ : 481.7444 ; found: 481.74402 .

Ibrutinib-alkyne (6). DiPEA (4.0 eq., $70 \mu \mathrm{L}, 0.4 \mathrm{mmol})$ and 6-heptynoic-OSu ${ }^{18}$ (2.2 eq., $4.9 \mathrm{mg}, 0.25 \mathrm{mmol}$ ) were added to a solution of crude amine $20(42 \mathrm{mg}, 0.1 \mathrm{mmol})$ in DMF $(0.5 \mathrm{~mL})$. The reaction mixture was stirred overnight before being evaporated. The title compound was obtained after RP-HPLC purification (linear gradient $40 \% \rightarrow 60 \%$ ACN in $\mathrm{H}_{2} \mathrm{O}, 0.1 \%$ TFA, $15 \mathrm{~min}$ ) as a white solid (yield: $32.92 \mathrm{mg}$, $35.87 \mu \mathrm{mol}, 35.9 \%) . R_{\mathrm{F}}=0.05$ (90\% EtOAc/Pentane). ${ }^{1} \mathrm{H}$ NMR $\left(600 \mathrm{MHz}, \mathrm{DMSO}_{\mathrm{d}}\right.$ ): $\delta 8.39(\mathrm{~s}, 1 \mathrm{H}), 8.03$ (br s, 1H), 7.67-7.66 (m, 2H), $7.44(\mathrm{t}, J=7.2 \mathrm{~Hz}, 2 \mathrm{H}), 7.19(\mathrm{t}, J=7.2 \mathrm{~Hz}, 1 \mathrm{H}), 7.16$ (d, $J=9.0 \mathrm{~Hz}, 2 \mathrm{H}), 7.13(\mathrm{~d}, J=8.4 \mathrm{~Hz}, 2 \mathrm{H}), 6.85(\mathrm{~d}, J=15.0 \mathrm{~Hz}$, $0.5 \mathrm{H}), 6.70(\mathrm{~d}, J=15.0 \mathrm{~Hz}, 0.5 \mathrm{H}), 6.63-6.61(\mathrm{~m}, 0.5 \mathrm{H})$, 6.56-6.54 (m, 0.5H), 4.77-4.71 (m, 2H), 4.57 (d, $J=12 \mathrm{~Hz}, 1 \mathrm{H})$, $4.19(\mathrm{~d}, J=12.0 \mathrm{~Hz}, 2 \mathrm{H}), 4.06(\mathrm{~d}, J=12.6 \mathrm{~Hz}, 1 \mathrm{H}), 3.75(\mathrm{t}, J=$ $11.4 \mathrm{~Hz}, 1 \mathrm{H}), 3.58(\mathrm{~s}, 1 \mathrm{H}), 3.44(\mathrm{~s}, 1 \mathrm{H}), 3.35$ (br s, $3 \mathrm{H}), 3.23$ (q, $J=11.4 \mathrm{~Hz}, J=22.2 \mathrm{~Hz}, 3 \mathrm{H}), 3.07-2.93(\mathrm{~m}, 4 \mathrm{H}), 2.73(\mathrm{~s}, 1 \mathrm{H})$, 2.28-2.24 (m, 1H), 2.20 (br s, 3H), 2.12-2.11 (m, 2H), 1.95-1.93 $(\mathrm{m}, 1 \mathrm{H}), 1.63-1.58(\mathrm{~m}, 3 \mathrm{H}), 1.47-1.44(\mathrm{~m}, 2 \mathrm{H}) .{ }^{13} \mathrm{C} \mathrm{NMR}$ (150 MHz, DMSO-d ${ }_{6}$ ): $\delta 174.26,163.81,157.40,156.58,156.18$, $152.98,144.44,130.12$, 127.16, 126.12, 123.63, 119.00, 115.78, $97.15,85.35,71.18,62.04,61.17,52.95,52.33,50.06,19.23$, $45.70,45.19,41.60,34.66,34.35,29.53,27.51,24.80,24.51$, 23.48, 17.43. IR film $\left(\mathrm{cm}^{-1}\right): 3290.7,2940.0,1663.7,1614.5$, 1520.9, 1490.1, 1455.4, 1235.5, 1198.8, 1131.3, 831.4, 711.2. HRMS: calcd for $\mathrm{C}_{39} \mathrm{H}_{47} \mathrm{~N}_{9} \mathrm{O}_{3}\left[\mathrm{M}+2 \mathrm{H}^{2+}\right]$ : 345.69737; found: 345.69732.

Ibrutinib- $\mathbf{N}_{3}$ (7). DiPEA (4.0 eq., $\left.70 \mu \mathrm{L}, 0.4 \mathrm{mmol}\right)$ and azido-PNP ester ${ }^{19}$ (2.5 eq., $63 \mathrm{mg}, 0.25 \mathrm{mmol}$ ) were added to a solution of crude amine 20 (42 $\mathrm{mg}, 0.1 \mathrm{mmol}$ ) in DMF $(0.5 \mathrm{~mL})$. The reaction mixture was stirred overnight before being evaporated. The title compound was obtained after RP-HPLC purification (linear gradient $40 \% \rightarrow 60 \%$ ACN in $\mathrm{H}_{2} \mathrm{O}, 0.1 \%$ TFA, $15 \mathrm{~min}$ ) as a white solid (yield: $20.39 \mathrm{mg}$, $22.14 \mu \mathrm{mol}, 22.1 \%$ ). ${ }^{1} \mathrm{H}$ NMR (600 MHz, DMSO-d ${ }_{6}$ ): $\delta 8.37$ (s, $1 \mathrm{H}), 8.08$ (br s, 1H), 7.66 (br s, 2H), 7.44 (t, $J=8.4 \mathrm{~Hz}, 2 \mathrm{H}), 7.20$ $(\mathrm{t}, J=7.2 \mathrm{~Hz}, 1 \mathrm{H}), 7.16(\mathrm{~d}, J=9.0 \mathrm{~Hz}, 2 \mathrm{H}), 7.13(\mathrm{~d}, J=8.4 \mathrm{~Hz}$, $2 \mathrm{H}), 6.84(\mathrm{~d}, J=15.0 \mathrm{~Hz}, 0.5 \mathrm{H}), 6.70(\mathrm{~d}, J=14.4 \mathrm{~Hz}, 0.5 \mathrm{H})$, 6.63-6.60 (m, 0.5H), 6.56-6.52 (m, 0.5H), 4.76-4.71 (m, 1H), $4.56(\mathrm{~d}, J=12.0 \mathrm{~Hz}, 0.5 \mathrm{H}), 4.19$ (d, $J=12.0 \mathrm{~Hz}, 0.5 \mathrm{H}), 4.06$ (d, $J=12.6 \mathrm{~Hz}, 0.5 \mathrm{H}), 3.75(\mathrm{t}, J=10.2 \mathrm{~Hz}, 0.5 \mathrm{H}), 3.37-3.33(\mathrm{~m}$, $4 \mathrm{H}), 3.23-3.20(\mathrm{~m}, 2 \mathrm{H}), 3.07-2.97(\mathrm{~m}, 4 \mathrm{H}), 2.31-2.24(\mathrm{~m}, 2 \mathrm{H})$, 2.19-2.13 (m, 6H), 1.95-1.93 (m, 2H), 1.77-1.75 (m, 4H), 1.63-1.53 (m, 2H). ${ }^{13} \mathrm{C}$ NMR (150 MHz, DMSO-d 6 ): $\delta$ 171.95, 163.81, 157.37, 156.19, 153.07, 152.79, 144.31, 143.91, 130.12, $127.25,126.13,123.85,119.00,115.78,97.17,56.67,55.04$, $52.92,52.30,50.16,49.30,45.71,45.19,41.60,34.07,32.12$, 29.54, 29.38, 24.81, 24.29, 23.18, 22.94. IR film ( $\left.\mathrm{cm}^{-1}\right): 3317.7$, 2097.7, 1671.4, 1587.5, 1520.9, 1490.1, 1437.0, 1236.4, 1201.7, 1131.3, 760.3, 613.4. HRMS: calcd for $\mathrm{C}_{36} \mathrm{H}_{44} \mathrm{~N}_{12} \mathrm{O}_{3}\left[\mathrm{M}+2 \mathrm{H}^{2+}\right]$ : 347.19024; found: 347.19022 .

Ibrutinib-norbornene (8). Azido-ibrutinib 7 (69 mg, $0.1 \mathrm{mmol}$ ) and $\mathrm{N}$-(2-propynyl)-5-norbornene-2-carboxamide ${ }^{8}$ (1.5 eq., $26.3 \mathrm{mg}, 0.15 \mathrm{mmol}$ ) were dissolved in DMF (0.5 mL). The reaction mixture was stirred overnight after addition of $\mathrm{CuSO}_{4} \cdot 5 \mathrm{H}_{2} \mathrm{O}$ (0.2 eq., $20 \mu \mathrm{L} 1 \mathrm{M}$ in $\left.\mathrm{H}_{2} \mathrm{O}, 20 \mu \mathrm{mol}\right)$ and sodium ascorbate ( 0.4 eq., $40 \mu \mathrm{L} 1 \mathrm{M}$ in $\mathrm{H}_{2} \mathrm{O}, 40 \mu \mathrm{mol}$ ). The mixture was then concentrated and purified by RP-HPLC (linear gradient $40 \% \rightarrow 60 \%$ ACN in $\mathrm{H}_{2} \mathrm{O}, 0.1 \%$ TFA, $15 \mathrm{~min}$ ) to yield the title compound as a white solid (yield: $10.75 \mathrm{mg}, 9.81 \mu \mathrm{mol}$, 10.2\%). ${ }^{1} \mathrm{H}$ NMR (600 MHz, DMSO-d ${ }_{6}$ ): $\delta 8.34$ (s, 1H), $8.09(\mathrm{br}$ s, $1 \mathrm{H}), 8.00$ (br s, 1H), $7.08(\mathrm{~s}, 1 \mathrm{H}), 7.67-7.66(\mathrm{~m}, 2 \mathrm{H}), 7.45(\mathrm{t}$, $J=7.2 \mathrm{~Hz}, 2 \mathrm{H}), 7.19$ (t, $J=7.2 \mathrm{~Hz}, 1 \mathrm{H}), 7.16(\mathrm{~d}, J=9.0 \mathrm{~Hz}, 2 \mathrm{H})$, $7.13(\mathrm{~d}, J=8.4 \mathrm{~Hz}, 2 \mathrm{H}), 6.84(\mathrm{~d}, J=14.4 \mathrm{~Hz}, 0.5 \mathrm{H}), 6.69(\mathrm{~d}, J=$ $14.4 \mathrm{~Hz}, 0.5 \mathrm{H}), 6.63-6.61(\mathrm{~m}, 0.5 \mathrm{H}), 6.56-6.53(\mathrm{~m}, 0.5 \mathrm{H})$, 6.10-6.08 (m, 1H), 5.80-5.78 (m, 1H), 4.75-4.70 (m, 1H), 4.56 
(br s, 1H), 4.33 (br s, 2H), 4.23 (br s, 2H), 4.08-4.05 (m, 1H), 3.78 (dd, $J=2.4 \mathrm{~Hz}, J=5.4 \mathrm{~Hz}, 2 \mathrm{H}$ ), 3.34 (br s, $2 \mathrm{H}$ ), 3.25-3.21 (m, 1H), 3.17 (br s, 1H), 3.14 (br s, 1H), 2.97-2.92 (br s, 2H), 2.82-2.79 (m, 2H), 2.28-2.23 (m, 1H), 2.16-2.14 (m, 1H), 2.12-2.09 (m, 4H), 2.07 (s, 1H), 2.11 (br s, 2H), 2.00-1.93 (m, $1 \mathrm{H}), 1.78-1.72(\mathrm{~m}, 3 \mathrm{H}), 1.68-1.54(\mathrm{~m}, 2 \mathrm{H}), 1.33-1.22(\mathrm{~m}, 9 \mathrm{H})$. ${ }^{13} \mathrm{C}$ NMR (150 MHz, DMSO-d $\left.\mathrm{d}_{6}\right): \delta$ 172.87, 172.66, 171.70, 163.80 , 158.32, 158.10, 157.32, 156.19, 153.20, 147.73, 145.42, $136.83,132.21,132.02,130.12127 .73,127.47,126.59,123.84$, 122.51, 118.99, 97.23, 81.61, 72.37, 69.75, 55.08, 54.03, 49.34, $48.71,47.37,46.64,45.48,43.23,42.07,34.33,31.85,28.41$, 27.83, 25.72. IR film $\left(\mathrm{cm}^{-1}\right): 3337.0,2945.4,1663.7,1518.0$, 1490.1, 1446.7, 1418.7, 1235.5, 1199.8, 1185.3, 839.1, 799.5, 720.4. HRMS: calcd for $\mathrm{C}_{47} \mathrm{H}_{57} \mathrm{~N}_{13} \mathrm{O}_{4}\left[\mathrm{M}+2 \mathrm{H}^{2+}\right]$ : 434.74010 ; found: 434.74012 .

\section{Experimental procedures: biochemistry} General

Ramos cells, a Burkitt's lymphoma B lymphocyte cell line, were cultured on Dulbecco's Modified Eagle Medium: Nutrient Mixture F-12 (DMEM/F-12) supplemented with 10\% Fetal Bovine Serum, $0.1 \mathrm{mg} \mathrm{mL}^{-1}$ penicillin, $0.1 \mathrm{mg} \mathrm{mL}^{-1}$ streptomycin in a $5 \% \mathrm{CO}_{2}$ humidified incubator at $37{ }^{\circ} \mathrm{C}$. Cell lysates were prepared from cell pellets by resuspension in cold digitonin lysis buffer (50 mM Tris pH $7=0,250 \mathrm{mM}$ sucrose, $5 \mathrm{mM}$ $\mathrm{MgCl}_{2}, 1 \mathrm{mM}$ DTT, $0.025 \%$ digitonin; $3 \times$ pellet volume), incubation on ice for $30 \mathrm{~min}$ and centrifugation for $15 \mathrm{~min}$ at $16000 g\left(4^{\circ} \mathrm{C}\right)$, after which the supernatants containing the cytosolic fractions were collected and the protein concentration was determined by Qubit@ Protein Assay kit. Precipitations of proteins was done using a chloroform/methanol (c/m) precipitation protocol. ${ }^{20}$ SDS-PAGE analysis: in-gel fluorescence was measured on a ChemiDoc MP system (Cy2 settings, 530/30 filter and Cy3 settings, 605/50 filter) and analysed using Image Lab 4.1. As a loading control gels were stained with Coomassie Blue. Protein standard is Dual Color protein standard (DC, Bio-Rad).

IMAP Reaction Buffer (10 mM Tris-HCl, $10 \mathrm{mM} \mathrm{MgCl} 2$, $0.01 \%$ Tween-20, $0.05 \% \mathrm{NaN}_{3} \mathrm{pH} 7.2$ ) and the IMAP Progressive Binding System (IMAP Progressive Binding Buffer A, IMAP Progressive Binding Buffer B, and IMAP Progressive binding Reagent), were all from Molecular Devices.

\section{IMAP FP assay}

Compounds 1, 6, 7 and $8(5 \mu \mathrm{L} 10 \times$ solution in DMSO/kinase reaction (KR)-buffer, such that the final concentration of DMSO was $4 \%$ ) and $100 \mathrm{mU} \mathrm{mL}^{-1}$ BTK (5 $\mu \mathrm{L} 100 \mathrm{mU} \mathrm{mL}^{-1}$ in KR-buffer) were incubated for $60 \mathrm{~min}$ at room temperature. Next, $50 \mathrm{nM}$ of fluoresceinated substrate $(5 \mu \mathrm{L} 200 \mathrm{nM}$ in KR-buffer) Fluorescein labeled Blk/Lyntide substrate (5FAM-EFPIYDFLPAKKK-NH2) and $5 \mu \mathrm{M}$ ATP $(5 \mu \mathrm{L} 20 \mu \mathrm{M}$ in KR-buffer) were added to the mixture and incubated for $120 \mathrm{~min}$ at room temperature. The reaction was stopped after $120 \mathrm{~min}$ by a $40 \mu \mathrm{L}$ addition of IMAP binding reagent in binding buffer and read on the Envision 2102 Multilabel Reader, Dichroic mirror D505FP/D535, exitation filter: $480 \mathrm{~nm}$ cwl. Parallel and perpendicular filters $535 \mathrm{~nm}$ cwl. For every measurement 18 wells were used as minimum wells (wells with ATP, $0 \%$ effect), 18 wells were used as maximum wells (wells without ATP, 100\% effect). 16 wells were used to measure the background signal, which contained no substrate. Enzyme, substrate, and ATP were prepared in kinase reaction buffer containing $1 \mathrm{mM}$ DTT. The IMAP binding reagent was $2000 \times$ diluted in the binding buffer.

\section{In vitro labeling of BTK in Ramos cells (ABPs 4 and 5)}

Ramos cell lysates ( $30 \mu \mathrm{g}$ total protein per experiment) in lysis buffer $(9 \mu \mathrm{L})$ were exposed to the indicated concentrations of the $\mathrm{ABP}(1 \mu \mathrm{L} 10 \times$ solution in DMSO $)$ for $1 \mathrm{~h}$ at room temperature. The reaction mixtures were then boiled for $5 \mathrm{~min}$ at $95{ }^{\circ} \mathrm{C}$ with $3.3 \mu \mathrm{L} 4 \times$ Laemmli's sample buffer containing 2-mercaptoethanol and resolved on 10\% SDS-PAGE, followed by fluorescence scanning (Cy2 or Cy3 settings) and CBB staining.

\section{In situ labelling of BTK in Ramos cells (ABPs 4 and 5)}

Ramos cells $\left( \pm 1 \times 10^{7}\right.$ cells per experiment) were exposed to the indicated concentrations of the $\mathrm{ABP}(1 \mu \mathrm{L} 10000 \times$ solution in DMSO) in $10 \mathrm{~mL}$ fresh medium for $4 \mathrm{~h}$ at $37^{\circ} \mathrm{C}$, before being centrifuged for $5 \mathrm{~min}$ at $1200 \mathrm{rpm}$, and washed with PBS (3×). The cell pellets were then flash frozen in liquid nitrogen and lysed in $30 \mu \mathrm{L}$ lysis buffer. The lysates $(30 \mu \mathrm{g}$ total protein per experiment) in lysis buffer $(10 \mu \mathrm{L})$ were boiled for $5 \mathrm{~min}$ at $95{ }^{\circ} \mathrm{C}$ with $3.3 \mu \mathrm{L} 4 \times$ Laemmli's sample buffer containing 2-mercaptoethanol and resolved on 10\% SDS-PAGE. In-gel visualization of the fluorescent labeling was performed in the wet gel slabs directly using Cy2 or Cy3 settings.

\section{Competition experiments of ABP 4 versus ABPs 6-8: in situ modification of BTK by ABP 4 and in vitro competition by ABPs 6-8}

Ramos cells $\left( \pm 5 \times 10^{6}\right.$ cells per experiment $)$ were seeded in $6 \mathrm{~cm}$ petri dishes and grown $2 \mathrm{~h}$ at $37{ }^{\circ} \mathrm{C}$, before being exposed to the indicated concentrations of $\mathrm{ABP}(2 \mu \mathrm{L} 1000 \times$ solution in DMSO) in $2 \mathrm{~mL}$ fresh medium for $3 \mathrm{~h}$ at $37^{\circ} \mathrm{C}$. Next, the cells were centrifuged for $5 \mathrm{~min}$ at $1200 \mathrm{rpm}$, and washed with PBS $(3 \times)$, before flash freezing the cell pellets in liquid nitrogen and cell lysis in $15 \mu \mathrm{L}$ lysis buffer. The lysates (30 $\mu \mathrm{g}$ total protein per experiment) in lysis buffer $(10 \mu \mathrm{L})$ were exposed to $1 \mu \mathrm{M}$ ABP $4(1.11 \mu \mathrm{L} 10 \times$ solution in DMSO) for $1 \mathrm{~h}$ at room temperature, boiled for $5 \mathrm{~min}$ at $95{ }^{\circ} \mathrm{C}$ with $3.7 \mu \mathrm{L} 4 \times$ Laemmli's sample buffer containing 2-mercaptoethanol and resolved on $10 \%$ SDS-PAGE. In-gel visualization of the fluorescent labeling was directly performed in the wet gel slabs using Cy2 or Cy3 settings.

\section{In vitro tetrazine ligation}

Ramos lysates (50 $\mu \mathrm{g}$ total protein per experiment) in lysis buffer $(9 \mu \mathrm{L})$ were exposed to $4 \mu \mathrm{M}$ ABP $8(1 \mu \mathrm{L} 40 \mu \mathrm{M}$ in DMSO) for $1 \mathrm{~h}$ at room temperature, followed by addition of $1 \% \operatorname{SDS}\left(1.11 \mu \mathrm{L} 10 \%\right.$ SDS in $\left.\mathrm{H}_{2} \mathrm{O}\right)$ and boiling for $5 \mathrm{~min}$ at 
$95{ }^{\circ} \mathrm{C}$. Hereafter, the lysates were exposed for $1 \mathrm{~h}$ at room temperature to the indicated concentrations of tetrazine $\mathbf{2 4}$ $(1.23 \mu \mathrm{L} 10 \times$ solution in DMSO). In control experiments, lysates were treated with $\mathrm{ABP} 4(1 \mu \mathrm{M})$ (positive control) or subjected to tetrazine labeling in the absence of ABP 8 (background control). As a negative control, tetrazine ligation was performed on lysates pretreated with $20 \mu \mathrm{M}$ ibrutinib (1). After the ligation reaction proteins were precipitated by $\mathrm{c} / \mathrm{m}$ precipitation and taken up in $10 \mu \mathrm{L} 8 \mathrm{M}$ urea and $3.5 \mu \mathrm{L} 4 \times$ Laemmli's sample buffer containing 2-mercaptoethanol, boiled for $5 \mathrm{~min}$ at $95{ }^{\circ} \mathrm{C}$ and resolved on $10 \%$ SDS-PAGE. In-gel visualization of the fluorescent labeling was performed in the wet gel slabs directly using Cy2 settings.

\section{In situ and post-lysis tetrazine ligation}

Ramos cells $\left( \pm 5 \times 10^{6}\right.$ cells per experiment) were seeded in $6 \mathrm{~cm}$ petri dishes and grown $2 \mathrm{~h}$ at $37^{\circ} \mathrm{C}$, before being exposed to $4 \mu \mathrm{M}$ ABP $8(2 \mu \mathrm{L} 1000 \times$ solution in DMSO) in $2 \mathrm{~mL}$ fresh medium for $3 \mathrm{~h}$ at $37^{\circ} \mathrm{C}$. After centrifugation of the cells for $5 \mathrm{~min}$ at $1200 \mathrm{rpm}$, the cells were washed with fresh medium for $5 \mathrm{~min}$ at $37^{\circ} \mathrm{C}(3 \times)$, and then exposed to $25 \mu \mathrm{M}$ of tetrazine 24 ( $4 \mu \mathrm{L} 10 \times$ solution in DMSO) in $4 \mathrm{~mL}$ fresh medium for $1 \mathrm{~h}$ at $37^{\circ} \mathrm{C}$. As a positive control, cells were exposed to ABP $4(1 \mu \mathrm{M})$ for $3 \mathrm{~h}$ at $37^{\circ} \mathrm{C}$. As a background control, cells were lysed and subjected to tetrazine labeling in the absence of ABP 8. Next, cells were harvested in PBS, centrifuged for $5 \mathrm{~min}$ at $1200 \mathrm{rpm}$, and washed with PBS (3×), before flash freezing the cell pellets in liquid nitrogen and cell lysis in $15 \mu \mathrm{L}$ lysis buffer. The lysates $(50 \mu \mathrm{g}$ total protein per experiment) in lysis buffer $(10 \mu \mathrm{L})$ were precipitated by $\mathrm{c} / \mathrm{m}$ precipitation and taken up in $10 \mu \mathrm{L} 8 \mathrm{M}$ urea and $3.5 \mu \mathrm{L} 4 \times$ Laemmli's sample buffer containing 2-mercaptoethanol, boiled for $5 \mathrm{~min}$ at $95{ }^{\circ} \mathrm{C}$. the proteins were resolved on $10 \%$ SDS-PAGE. Fluorescence was measured in the wet gel slabs using Cy2 settings.

For post-lysis ligation experiments, cells were harvested directly after treatment with ABP 8 and lysed. The lysates (50 $\mu \mathrm{g}$ total protein per experiment) in lysis buffer $(10 \mu \mathrm{L})$ were boiled for $5 \mathrm{~min}$ at $95{ }^{\circ} \mathrm{C}$ after addition of $1 \%$ SDS $(1.11 \mu \mathrm{L}$ $10 \%$ SDS in $\mathrm{H}_{2} \mathrm{O}$ ) and boiling for $5 \mathrm{~min}$ at $95{ }^{\circ} \mathrm{C}$. Next, the lysates were exposed for $1 \mathrm{~h}$ at room temperature to $25 \mu \mathrm{M}$ of tetrazine $24(1.23 \mu \mathrm{L} 10 \times$ solution in DMSO). After the ligation reaction proteins were precipitated by $\mathrm{c} / \mathrm{m}$ precipitation and taken up in $10 \mu \mathrm{L} 8 \mathrm{M}$ urea and $3.5 \mu \mathrm{L} 4 \times$ Laemmli's sample buffer containing 2-mercaptoethanol, boiled for $5 \mathrm{~min}$ at $95{ }^{\circ} \mathrm{C}$ and resolved on $10 \%$ SDS-PAGE. In-gel visualization of the fluorescent labeling was performed in the wet gel slabs directly using Cy2 settings.

\section{Copper(I)-catalyzed click ligation in vitro}

Ramos lysates $(50 \mu \mathrm{g}$ total protein per experiment) in lysis buffer $(9 \mu \mathrm{L})$ were exposed to $4 \mu \mathrm{M}$ ABP 6 or $7(1 \mu \mathrm{L} 40 \mu \mathrm{M}$ in DMSO) for $1 \mathrm{~h}$ at room temperature. The reaction mixtures were subsequently diluted with an additional $9 \mu \mathrm{L}$ buffer containing $6.5 \mathrm{mM} \mathrm{CuSO}_{4}\left(0.58 \mu \mathrm{L} 100 \mathrm{mM}\right.$ in $\left.\mathrm{H}_{2} \mathrm{O}\right), 6.5 \mathrm{mM}$ THPTA $\left(0.58 \mu \mathrm{L} 100 \mathrm{mM}\right.$ in $\left.\mathrm{H}_{2} \mathrm{O}\right), 6.5 \mathrm{mM}$ sodium L-ascorbate $\left(0.58 \mu \mathrm{L} 100 \mathrm{mM}\right.$ in $\left.\mathrm{H}_{2} \mathrm{O}\right)$ and exposed for $1 \mathrm{~h}$ at room temperature to the indicated concentrations of azide 22 (reaction with 6) or alkyne 23 (reaction with 7) (1 $\mathrm{L} \mathrm{L} 20 \times$ solution in DMSO). In control experiments, lysates were treated with ABP $4(1 \mu \mathrm{M})$ (positive control) or subjected to azide or alkyne labeling in the absence of an ABP (background control). Alternatively, click ligation was performed on lysates pretreated with $20 \mu \mathrm{M}$ ibrutinib (1) (negative control). Next, proteins were precipitated by $\mathrm{c} / \mathrm{m}$ precipitation and taken up in $10 \mu \mathrm{L} 8 \mathrm{M}$ urea and 3.5 $\mu \mathrm{L} 4 \times$ Laemmli's sample buffer containing 2-mercaptoethanol, boiled for $5 \mathrm{~min}$ at $95{ }^{\circ} \mathrm{C}$ and resolved on $10 \%$ SDS-PAGE. In-gel visualization of the fluorescent labeling was performed in the wet gel slabs directly using Cy2 settings.

\section{In situ modification of BTK by ABPs 6 or 7 followed by in vitro copper(I)-catalyzed click ligation}

Ramos cells $\left( \pm 5 \times 10^{6}\right.$ cells per experiment) were seeded in $6 \mathrm{~cm}$ petri dishes and grown $2 \mathrm{~h}$ at $37{ }^{\circ} \mathrm{C}$, before being exposed to $4 \mu \mathrm{M}$ ABP 6 or $7(2 \mu \mathrm{L} 1000 \times$ solution in DMSO) in $2 \mathrm{~mL}$ fresh medium for $3 \mathrm{~h}$ at $37^{\circ} \mathrm{C}$. As a positive control, cells were exposed to ABP $4(1 \mu \mathrm{M})$ for $3 \mathrm{~h}$ at $37^{\circ} \mathrm{C}$. As a background control, cells were lysed and subjected to click labeling in the absence of ABP 6 or 7. Next, the cells were centrifuged for $5 \mathrm{~min}$ at $1200 \mathrm{rpm}$, and washed with PBS (3×), before flash freezing the cell pellets in liquid nitrogen and cell lysis in $15 \mu \mathrm{L}$ lysis buffer. The lysates (50 $\mu \mathrm{g}$ total protein per experiment) in lysis buffer $(10 \mu \mathrm{L})$ were diluted with an additional $9 \mu \mathrm{L}$ buffer containing $6.5 \mathrm{mM} \mathrm{CuSO}_{4}\left(0.58 \mu \mathrm{L} 100 \mathrm{mM}\right.$ in $\left.\mathrm{H}_{2} \mathrm{O}\right)$, $6.5 \mathrm{mM}$ THPTA $\left(0.58 \mu \mathrm{L} 100 \mathrm{mM}\right.$ in $\left.\mathrm{H}_{2} \mathrm{O}\right), 6.5 \mathrm{mM}$ sodium L-ascorbate $\left(0.58 \mu \mathrm{L} 100 \mathrm{mM}\right.$ in $\left.\mathrm{H}_{2} \mathrm{O}\right)$ and exposed for $1 \mathrm{~h}$ at room temperature to $25 \mu \mathrm{M}$ of azide 22 (reaction with 6) or alkyne 23 (reaction with 7$)(1 \mu \mathrm{L} 20 \times$ solution in DMSO). Next, proteins were precipitated by $\mathrm{c} / \mathrm{m}$ precipitation and taken up in $10 \mu \mathrm{L} 8 \mathrm{M}$ urea and $3.5 \mu \mathrm{L} 4 \times$ Laemmli's sample buffer containing 2-mercaptoethanol, boiled for $5 \mathrm{~min}$ at $95{ }^{\circ} \mathrm{C}$ and resolved on $10 \%$ SDS-PAGE. In-gel visualization of the fluorescent labeling was performed in the wet gel slabs directly using Cy2 settings.

\section{Acknowledgements}

The Netherlands Organization for Scientific Research (NWO-CW, Mozaiek grant to NL) and the European Research Council (ERC, Advanced Grant to HSO) are acknowledged for the financial support.

\section{References}

1 (a) C. M. Lewis, C. Broussard, M. J. Czar and P. L. Schwartzberg, Curr. Opin. Immunol., 2001, 13, 317; (b) A. B. Satterthwaite and O. N. Witte, Immunol. Rev., 2000, 175, 120; (c) W. N. Khan, Immunol. Res., 2001, 23, 147.

2 (a) R. E. Davis, V. N. Ngo, G. Lenz, P. Tolar, R. M. Young, P. B. Romesser, H. Kohlhammer, L. Lamy, H. Zhao, 
Y. Yang, W. Xu, A. L. Shaffer, G. Wright, W. Xiao, J. Powell, J. Jiang, C. J. Thomas, A. Rosenwald, G. Ott, H. K. MullerHermelink, R. D. Gascoyne, J. M. Connors, N. A. Johnson, L. M. Rimsza, E. Campo, E. S. Jaffe, W. H. Wilson, J. Delabie, E. B. Smeland, R. I. Fisher, R. M. Braziel, R. R. Tubbs, J. R. Cook, D. D. Weisenburger, W. C. Chan, S. K. Pierce and L. M. Staudt, Nature, 2010, 463, 88; (b) M. Cinar, F. Hamedani, Z. Mo, B. Cinar, H. M. Amin and S. Alkan, Leuk. Res., 2013, 37, 1271; (c) M. F. M. De Rooij, A. Kuil, C. R. Geest, E. Eldering, B. Y. Chang, J. J. Buggy, S. T. Pals and M. Spaargaren, Blood, 2012, 119, 2590; (d) G. Yang, Y. Zhou, X. Liu, L. Xu, Y. Cao, R. J. Manning, C. J. Patterson, S. J. Buhrlage, N. Gray, Y.-T. Tai, K. C. Anderson, Z. R. Hunter and S. P. Treon, Blood, 2013, 122, 1222.

3 (a) F. Cameron and M. Sanford, Drugs, 2014, 74, 263; (b) US Food and Drug Administration. Imbruvica, 2013. (Accessed 9 December 2013). (c) L. A. Honigberg, A. M. Smith, M. Sirisawas, E. Verner, D. Loury, B. Chang, S. Li, Z. Pan, D. H. Thamm, R. A. Miller and J. J. Buggy, Proc. Natl. Acad. Sci. U. S. A., 2010, 107, 13075-13080; (d) Z. Pan, H. Scheerens, S.-J. Li, B. E. Schultz, P. A. Sprengeler, L. C. Burrill, R. V. Mendonca, M. D. Seeney, K. C. K. Scott, P. G. Grothaus, D. A. Jeffery, J. M. Spoerke, L. A. Honigberg, P. R. Young, S. A. Dalrymple and J. T. Palmer, Chem. Med. Chem., 2007, 2, 58.

4 T. Barf and A. Kaptein, J. Med. Chem., 2012, 55, 6243.

5 (a) Y. Liu, M. P. Patricelli and B. F. Cravatt, Proc. Natl. Acad. Sci. U. S. A., 1999, 96, 14694; (b) B. F. Cravatt, A. T. Wright and J. W. Kozarich, Annu. Rev. Biochem., 2008, 77, 383; (c) M. J. Niphakis and B. F. Cravatt, Annu. Rev. Biochem., 2014, 83, 341.

6 B. R. Lanning, L. R. Whitby, M. M. Dix, J. Douhan, A. M. Gilbert, E. C. Hett, T. O. Johnson, C. Joslyn, J. C. Kath, S. Niessen, L. R. Roberts, M. E. Schnute, C. Wang, J. J. Hulce, B. Wei, L. O. Whiteley, M. M. Hayward and B. F. Cravatt, Nat. Chem. Biol., 2014, 10, 760.
7 L. I. Willems, W. A. van der Linden, N. Li, K.-Y. Li, N. Liu, S. Hoogendoorn, G. A. van der Marel, B. I. Florea and H. S. Overkleeft, Acc. Chem. Res., 2011, 44, 718.

8 L. I. Willems, N. Li, B. I. Florea, M. Ruben, G. A. van der Marel and H. S. Overkleeft, Angew. Chem., Int. Ed., 2012, 51, 4431.

9 (a) A. Turetsky, E. Kim, R. H. Kohler, M. A. Miller and R. Weissleder, Sci. Rep., 2014, 4, 4782; (b) Z. Pan, S. J. Li, H. Scheerens, L. Honigberg and E. verner, US Pat, US 2008/ 0214501 A1, 2008.

10 L. Honigberg, E. Verner and Z. Pan, US Pat, US 2008/ $0076921 \mathrm{~A} 1,2008$.

11 The Walter and Eliza Hall institute of medical research, WO, 2012003544 A1, 2012.

12 Astrazeneca AB, US Pat, US6518286 B1, 2003.

13 M. Han, Y. Han, C. Song and H.-G. Hahn, Bull. Korean Chem. Soc., 2012, 33, 2597.

14 H. D. H. Showalter, J. L. Johnson, J. M. Hoftiezer, W. R. Turner, L. M. Werbel, W. R. Leopold, J. L. Shillis, R. C. Jackson and E. F. Elslager, J. Med. Chem., 1987, 30, 121.

15 N. J. Matovic, P. Y. Hayes, K. Penman, R. P. Lehmann and J. J. de Voss, J. Org. Chem., 2011, 76, 4467.

16 S. E. Boiadjiev and D. A. Lightner, J. Heterocycl. Chem., 2003, 40, 181.

17 M. Verdoes, B. I. Florea, V. Menendez-Benito, C. J. Maynard, M. D. Witte, W. A. Van der Linden, A. M. C. H. van den Nieuwendijk, T. Hofmann, C. R. Berkers, F. W. van Leeuwen, T. A. Groothuis, M. A. Leeuwenburgh, H. Ovaa, J. J. Neefjes, D. V. Filippov, G. A. van der Marel, N. P. Dantuma and H. S. Overkleeft, Chem. Biol., 2006, 13, 1217.

18 A. E. Speers, G. C. Adam and B. F. Cravatt, J. Am. Chem. Soc., 2003, 125, 1217.

19 U. Hillaert, M. Verdoes, B. I. Florea, A. Saragliadis, K. L. L. Habets, J. Kuiper, S. van Calenbergh, F. Ossendorp, G. A. van der Marel, C. Driessen and H. S. Overkleeft, Angew. Chem., Int. Ed., 2009, 48, 1629.

20 D. Wessel and U. I. Flügge, Anal. Biochem., 1984, 138, 141. 